\title{
ChemComm
}

Cite this: Chem. Commun., 2011, 47, 7567-7582

\section{Biomimetic and bioinspired silica: recent developments and applications}

\author{
Siddharth V. Patwardhan* \\ Received 17th December 2010, Accepted 24th March 2011 \\ DOI: $10.1039 / \mathrm{c0cc05648k}$
}

\begin{abstract}
In a previous review of biological and bioinspired silica formation (S. V. Patwardhan et al., Chem. Commun., 2005, 1113 [ref. 1]), we have identified and discussed the roles that organic molecules (additives) play in silica formation in vitro. Tremendous progress has been made in this field since and this review attempts to capture, with selected examples from the literature, the key advances in synthesising and controlling properties of silica-based materials using bioinspired approaches, i.e. conditions of near-neutral $\mathrm{pH}$, all aqueous environments and room temperature. One important reason to investigate biosilicifying systems is to be able to develop novel materials and/or technologies suitable for a wide range of applications. Therefore, this review will also focus on applications arising from research on biological and bioinspired silica. A range of applications such as in the areas of sensors, coatings, hybrid materials, catalysis and biocatalysis and drug delivery have started appearing. Furthermore, scale-up of this technology suitable for large-scale manufacturing has proven the potential of biologically inspired synthesis.
\end{abstract}

\section{Background}

The current industrial capacity for silica production is $\sim 1 \times 10^{6}$ tonnes per annum, while silica-based materials form $\sim £ 2$ billion industry. ${ }^{2}$ This industry covers a wide range of applications in catalysis, separations, food and drug

Department of Chemical and Process Engineering, University of Strathclyde, 75 Montrose Street, Glasgow G1 1XJ, UK.

E-mail: Siddharth.Patwardhan@strath.ac.uk;

Fax: +44(0) 141548 2539; Tel: + 44(0) 1415485786

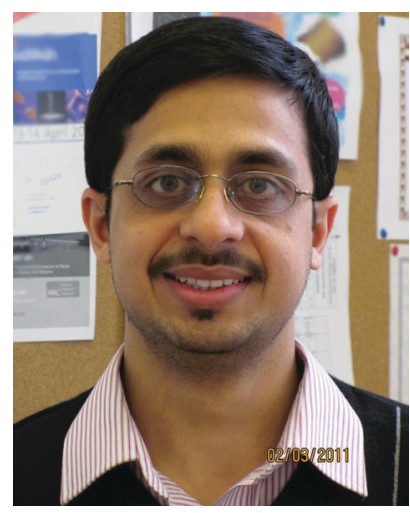

Siddharth V. Patwardhan

Dr Patwardhan obtained BEng in Petrochemical Engineering followed by MS and PhD in Materials Science. He performed postdoctoral research at the University of Delaware and Nottingham Trent University. After a brief period of lectureship at Nottingham Trent University, Siddharth is now a lecturer at the University of Strathclyde. Dr Patwardhan's research interests include inorganic nanomaterials at biointerface, green routes to nanomaterials, catalysis and biocatalysis, and self-assembly of biomacromolecules. He has published over 40 articles, delivered over 30 conference presentations, co-organized symposia on Synthetic and Biological Macromolecules for Emerging Nanotechnologies and is a co-founder and an associate editor of journal SILICON. technology, biomedical materials and paints. $^{3,4}$ Biology produces, through biomineralisation, inorganic materials such as silica at scales $>6.7 \times 10^{9}$ tonnes of silicon per year, ${ }^{5,6}$ but all under mild conditions and achieves superior control over materials produced..$^{7-10}$ The scale of biological silica deposition is orders of magnitude greater than the industrial capacity. It appears that biology has identified 'clever' and green routes to produce ornate structures of nanomaterials ${ }^{11}$ and an understanding of the secrets of biological silica formation could lead to materials with novel applications and/or new technologies for nanomaterials production.

The outline and the scope of the review are as follows. This review will discuss briefly the process of biological silica formation, highlighting the key features. We will then focus on recent advances and trends in bioinspired or biomimetic silica synthesis and finally present, with selected examples, applications arising from bioinspired silica research. It should be noted that only selected examples have been presented in order to aid the ongoing discussions and the readers are encouraged to explore further with the help of extensive list of references provided, while studies not included are by no means less important. The review will not consider geological and environmental aspects of silica and biosilica.

\section{Biosilicification}

An accurate definition of biological silica formationbiosilicification - has been recently provided: "the movement of silicic acid from environments in which its concentration does not exceed its solubility $(<2 \mathrm{mmol} / \mathrm{L})$ to intracellular or systemic compartments in which it is accumulated for subsequent deposition as amorphous hydrated silica". ${ }^{12}$ Therefore, in this 
review biosilicification is used for describing the biosynthesis of silica that occurs in vivo. In addition, biosilica should be understood as silica synthesised in vivo and not to be confused with silica produced in vitro, even though one is using biomolecules such as peptides and proteins to facilitate the reaction. Biological systems ranging from microorganisms to animals and higher plants actively uptake, accumulate and deposit silica. Biosilicifying organisms include diatoms (micro-alga), radiolaria, sponges and plants (e.g. horsetail and rice leaves). This review is written from a materials scientist's viewpoint and is not intended to provide a detailed account of biosilicification; readers are directed to some excellent monographs on biological silica formation., ${ }^{73-21}$ Nonetheless, some fascinating features of biosilica are discussed with their relevance to developing bioinspired materials.

\subsection{Intriguing features of biosilicification}

Biosilica in organisms primarily serves as a mechanical/ structural support (e.g. cell walls of diatoms and silica in rice leaves), ${ }^{15,17,22,23}$ provides protection from predators (e.g. silica spicules from sponges) and acts as sensors (e.g. biosilica as optical fibres). ${ }^{24-26}$ Some of the outstanding features of biological silica formation are listed below and subsequently discussed with comparison being made to synthetic silica formation:

- Ornate and hierarchical structures;

- Mild pH;

- Ambient temperatures;

- Environmentally friendly and all-aqueous ("green");

- Controlled;

- Involvement of organic components.

As evident from Fig. 1, biosilica exhibits hierarchical organisation of particles and pores over several length scales
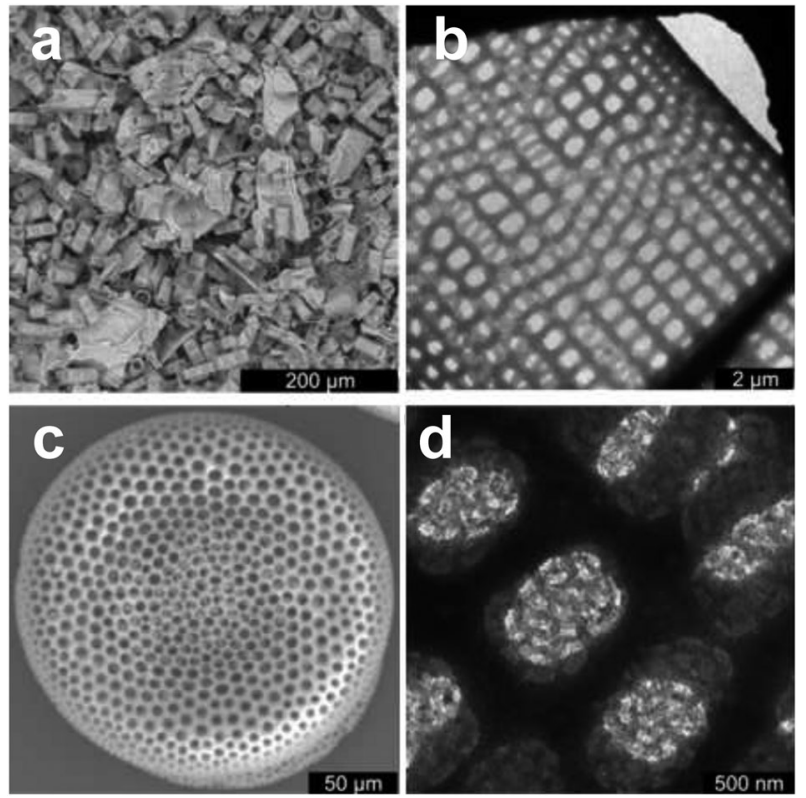

Fig. 1 Forms of biogenic silica: Electron Microscope images of biosilica frustules of diatoms illustrating their beauty and the hierarchical organisation. Images are copyright of Springer and reproduced with permission of Springer from ref. 244. ranging from tens of nanometres to tens or hundreds of micrometres. ${ }^{27}$ Such structural sophistication is rarely achieved in synthetic approaches, especially under mild conditions. The organised biosilica structures in diatoms have been proposed to exist over three length scales: microscale (of the order of the cell), mesoscale (higher order assemblies of biosilica particles and pores) and nanoscale (primary particles and their aggregates). ${ }^{13,14,28}$

A second, and perhaps the most interesting, facet of biosilicification is the mild $\mathrm{pH}$ and ambient temperatures (typically mildly acidic to neutral $\mathrm{pH}$ and $<40{ }^{\circ} \mathrm{C}$ ). ${ }^{29,30}$ Prior to the development of bioinspired silica synthesis, silica formation at near-neutral $\mathrm{pH}$ and room temperature had proven difficult. One of the reasons being the rate of hydrolysis has been reported to be the lowest at $\mathrm{pH}=7$ with gelation taking longer than at any other $\mathrm{pH} .{ }^{31,32}$ Typically, the synthetic approaches to silica and silicates involved solution based sol-gel chemistry operating at low temperature $\left(<100{ }^{\circ} \mathrm{C}\right) .{ }^{31,33-36}$ Sol-gel syntheses employ alkoxysilanes as silica precursors, which are toxic but also possess limited solubility in water and often a mixture of water and an alcohol as the reaction solvent is needed. Biosilica formation on the other hand occurs in all-aqueous environments and utilises (unsaturated) silicic acid-soluble and non-toxic form of silica-which typically occurs at $<200 \mu \mathrm{M}$ in natural waters. ${ }^{6,13,37}$

Biosilicification is under strict and indirect genetic control, where the mechanisms underpinning and the key processes involved in biosilicification such as silicic acid uptake, storage/ transport and deposition are biologically regulated. However, it is noted that the formation of $\mathrm{Si}-\mathrm{O}-\mathrm{C}, \mathrm{Si}-\mathrm{C}$ or $\mathrm{Si}-\mathrm{N}$ bonds in vivo have yet to be experimentally confirmed. Biochemical and biological research has revealed that biosilica formation involves organic biomolecules such as proteins, peptides and small amines in stages crucial to biosilica formation such as silicon uptake, transport and deposition. . $^{73,17,19,20}$

\subsection{Secrets at molecular level}

While one admires the way nature has 'optimised' the methods for the deposition of organised silica-based materials, it is fascinating to understand, on a molecular level, the workings of biosilicifying organisms. ${ }^{38}$ Combining approaches from molecular biology, genetics, protein science and cell biology, researchers have unveiled mechanistic secrets of biosilica formation (Fig. 2, top part). Examples include the identification of silicon transporters $(\mathrm{SiT})$ which are postulated to actively uptake silicic acid from the environment into the silicifying organisms; ${ }^{12,13,39-41}$ propylamines from diatoms and sponges that can rapidly precipitate silica in vitro in model reactions; ${ }^{42,43}$ and silicatein proteins from a range of silicifying sponges. $^{19,44-46}$

In addition to biological investigations, research on model systems in vitro has been fruitful in identification of mechanisms (Fig. 2, middle section). Such studies include, for example, probing the interactions between biomolecules and silicates in solution ${ }^{47-58}$ or understanding assembly and organisation of organic as well as inorganic building blocks in silica formation. ${ }^{59-61}$ In vitro experiments on silica 


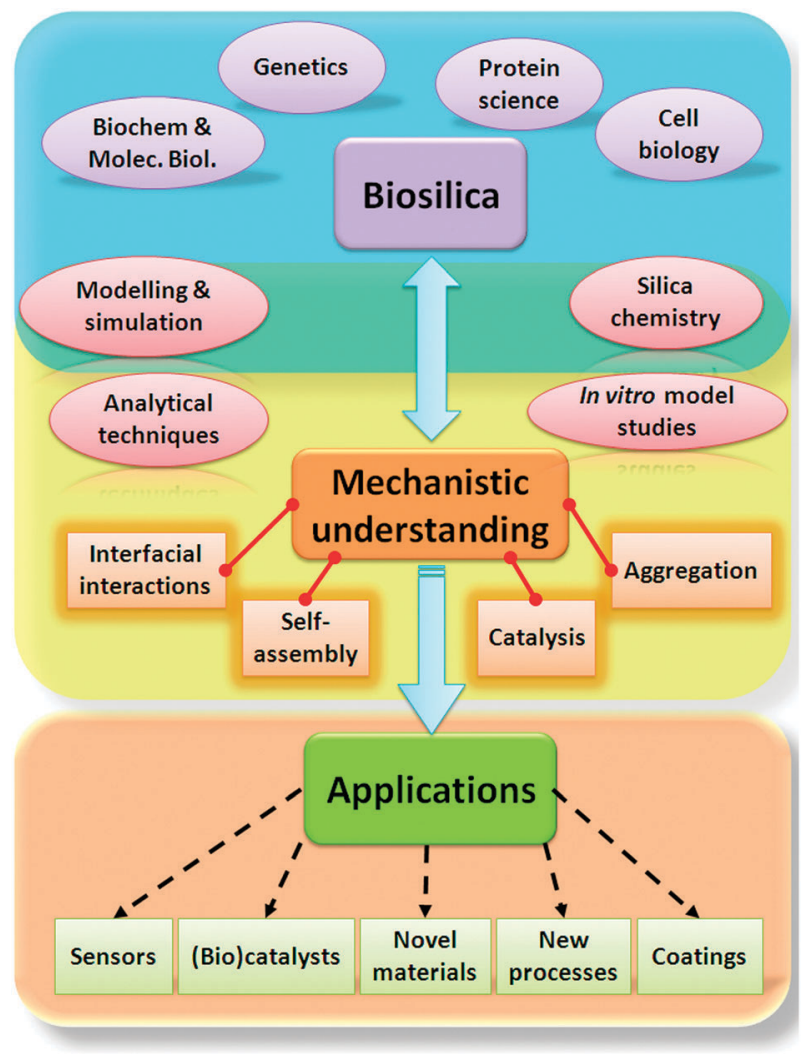

Fig. 2 Schematic representation of the journey from research on biosilica to applications arising (central rectangular boxes). Areas important for such research are shown (elliptical boxes). Block arrows indicate the direction of the flow of knowledge and information. Key mechanistic features are also presented. Dashed arrows point to the potential applications.

formation have developed bioinspired or green routes to silica, whereby silica formation under mild conditions has been achieved, ${ }^{1,62,63}$ and a range of applications are envisaged, as discussed in section 5 (Fig. 2, bottom section).

\subsection{Milestones in bioinspired silica research}

When we consider the timeline of important advances in the field of biological silica research, it appears that significant progress has been made in last 10-15 years (Fig. 3). However, it is noted that a substantial number of biosilica studies, in particular on cell biology, reported prior to 1990s have provided the groundwork for recent progress in gaining molecular-level understanding of biological silica formation and biosilicifying systems. With due respect to those investigations, since this review focuses on relatively key advances, especially those profoundly influencing in vitro silica formation, for further discussion the readers are directed to excellent reviews. ${ }^{13-16,39,64-66}$

Research in the late 1990s and early 2000s were dominated by the identification of silicon transporters in diatoms and plants and silica-depositing proteins and small amines in diatoms, plants and sponges (Fig. 3a). ${ }^{1,13,40,41,43-45,67-72}$ Genomes of two diatom species have been recently sequenced, enabling further understanding of biosilicification, ${ }^{73,74}$ with several genes associated with biosilica synthesis in diatoms
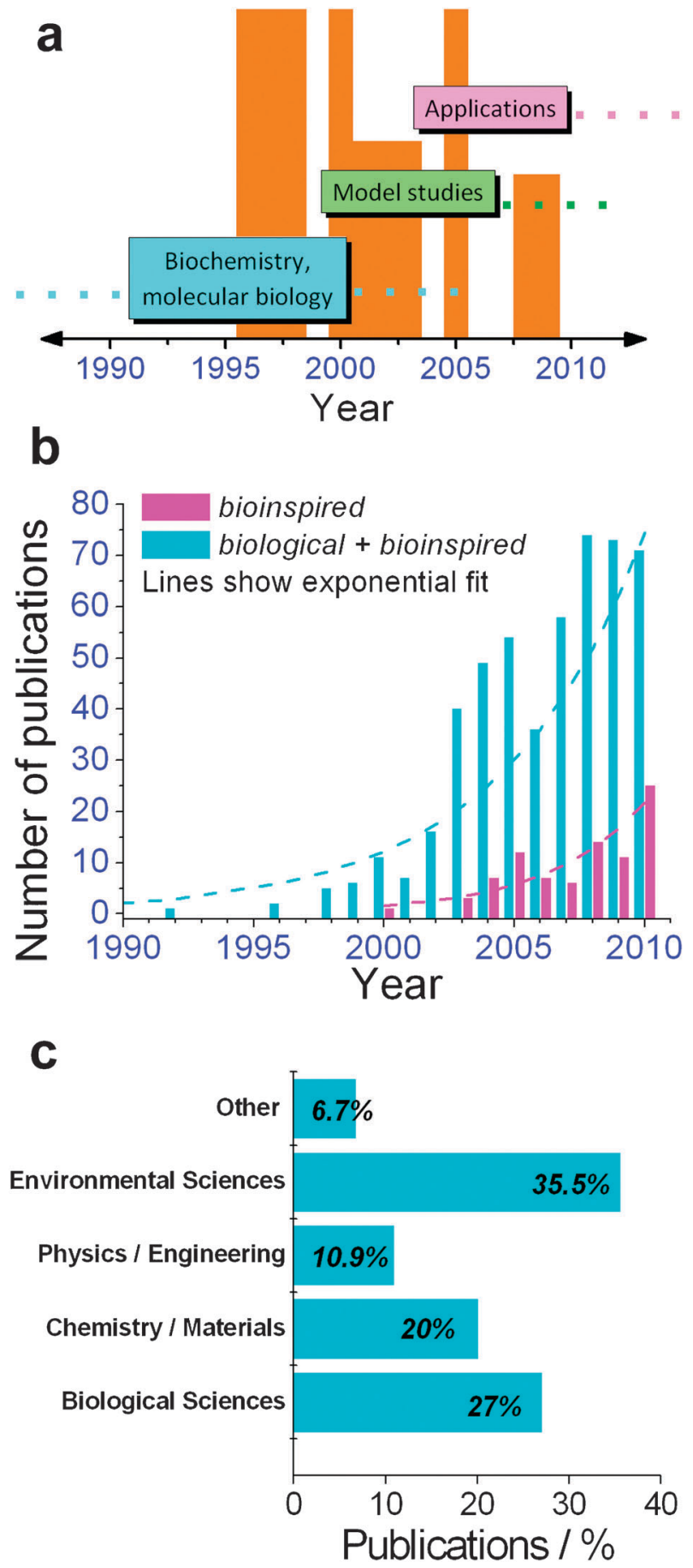

Fig. 3 (a) A pictorial presentation of milestones in biological and bioinspired silica as a function of time. The width of the bars roughly depict the number of publications while the height can be approximated to the importance/intensity of the discoveries. (b-c) The distribution of publications over time and broad subject disciplines. Data collected in February 2011 from SciFinder Scholar ${ }^{\circledR}$ (b) and ISI Web of Knowledge ${ }^{\mathbb{R}}$ in November 2010 (c).$^{75}$ The exponential fits in (b) are as follows: for biological silica $y=0.5676 e^{0.1806 x}\left(R^{2}=0.8642\right)$ and for bioinspired silica $y=0.0155 e^{0.2685 x}\left(R^{2}=0.8051\right)$.

identified. ${ }^{70}$ Furthermore, it has been demonstrated that the diatom biosilica synthesis cascade may be altered by the manipulation of specific biosynthetic pathways. ${ }^{70}$ 


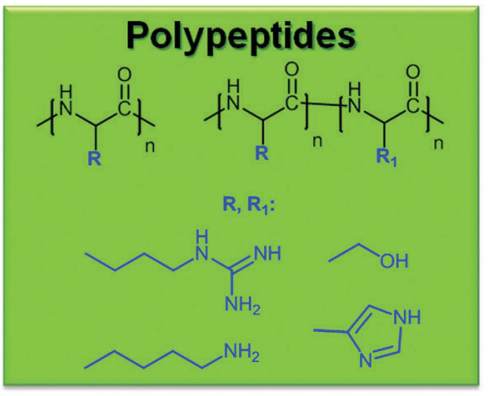

Polysaccharides
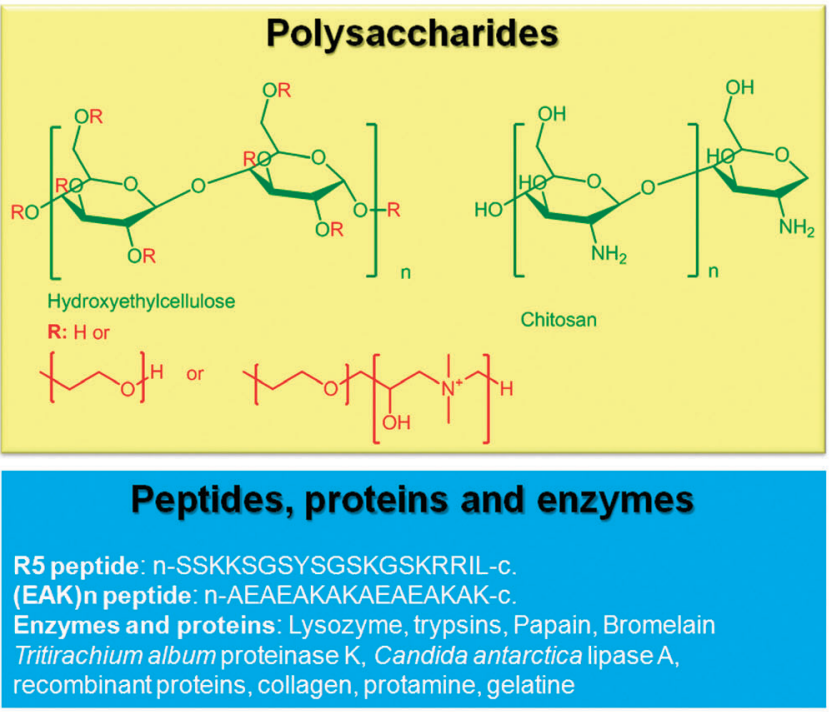
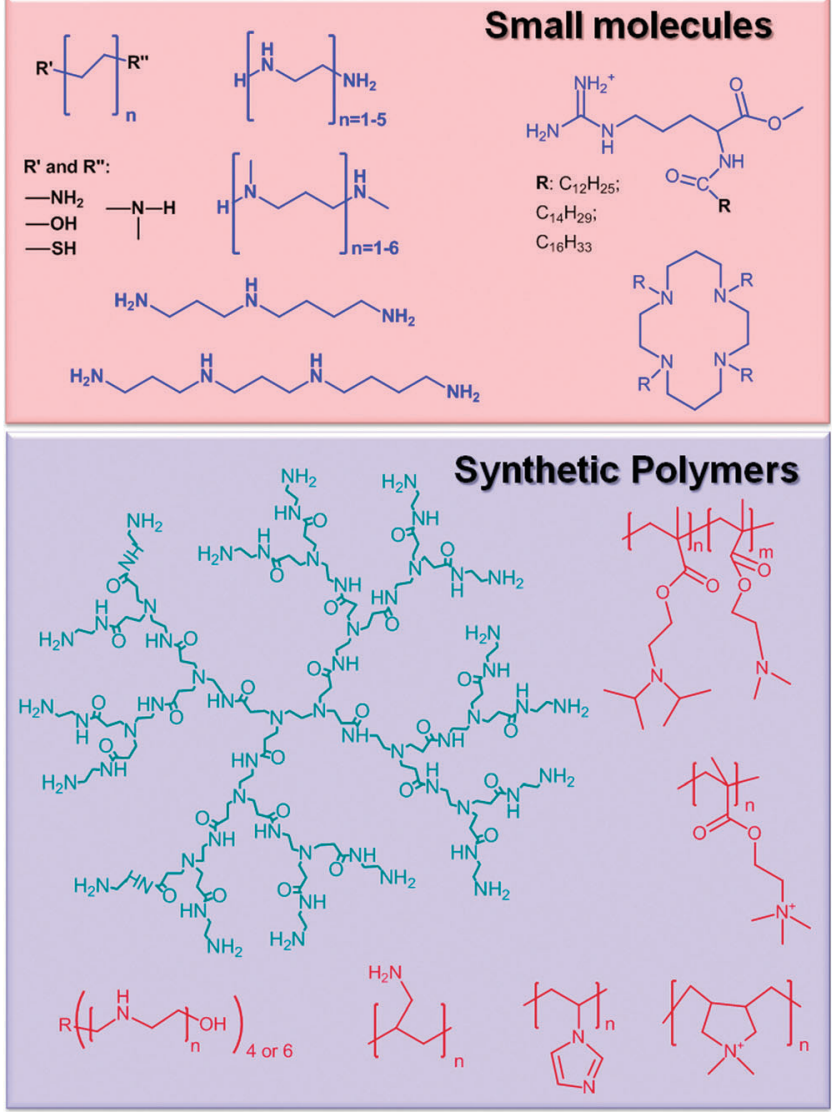

Fig. 4 Selected examples of the biological, bioderived, bioinspired and synthetic additives used in silica formation in vitro. These additives are shown in five groups of polypeptides, ${ }^{47,48,92,94,96-99,106,112}$ polysaccharides, ${ }^{115,134}$ peptides ${ }^{76,93,130} /$ proteins $^{56,117,131,245} /$ enzymes, $^{111,135}$ small molecules $^{47,57,107,108,133,136,139,150}$ and synthetic polymers (including dendrimers). ${ }^{91,105-107,109,110,113,114,116,118-122,124-129,132,137,138}$ See text for further information.

In the last ten years, we have seen an exponential growth in the research publications in the areas of biological and biologically inspired silica (for information on search keywords, see ref. 75); Fig. 3b. Although, all the missing pieces of the puzzle have not been discovered, a substantial amount of information on biosilica formation exists to date and therefore it is predicted that the growth in the research outcomes, especially in the area of bioinspired silica, will continue to with a rapid pace. A quick overview of the published articles on the topics of biological and biologically inspired silica categorised in broad subject disciplines is shown in Fig. $3 c{ }^{75}$

\section{From biological silica to bioinspired synthesis}

As detailed in the foregoing, biosilica is nanostructured and sophisticated and is produced by a complex biologically controlled process. One of the most important reasons behind learning about biosilicifying systems is to be able to develop novel materials and/or technologies suitable for applications. The question then is how do we transfer the knowledge obtained from biosilicification into in vitro synthesis of sophisticated silica-based materials and further develop biologically inspired functional materials or materials technologies. As an answer to this question, three ways are discussed below: identification of organic biomolecules involved in biosilicification; in vitro model studies using bioextracts; and the use of bioinspired custom-made additives.

\subsection{Involvement of biomolecules}

One way forward, as demonstrated by several research groups, is to employ biomolecules identified from biosilicifying organisms into in vitro model systems of silicification. For example, Sumper, Kröger and co-workers have identified a series of proteins (silaffins and cingulins) and propylamines from diatoms which have been proposed to be responsible for silica deposition in vivo. ${ }^{42,60,76-80}$ These biomolecules have demonstrated the ability to control silica formation in vitro in aqueous systems and under mild conditions of $\mathrm{pH}$ and temperature. Similarly, 'bioextracts' isolated from sponges (silicatein proteins and propylamines), ${ }^{43-45,81,82}$ plants ${ }^{67,69,83-85}$ and choanoflagellates ${ }^{86}$ have been successfully used to produce unique silicas in vitro. In the aforementioned model studies, not only was the controlled formation of nanostructured silica demonstrated, but mechanisms underpinning biosilicification have also started to surface.

\subsection{Effects of physical and chemical properties of biological and bioinspired additives}

Inspired from the intriguing ability of biomolecules to form silica in vitro, further attention had been given to the physical 
and chemical properties of the bioextracts. For example, the behaviour of organic bioextracts in solution or on surfaces and their interactions with silicates species were probed. ${ }^{60,87-90}$ Investigations of silaffin proteins and their assembly in vitro in the presence of varying salt concentration can be given as an example. ${ }^{59,60}$ However, due to the complex nature of bioextracts, and issues of their availability and purity, investigating their properties could prove difficult at times. Therefore, analogues of bioextracts have been used, allowing researchers access to simple or model biomolecules, nonbiological additives or in some cases, commercially available molecules.

Examples of such biologically derived additives include the R5 peptide which has an amino acid sequence derived from one of the silaffin proteins; several homo- and block co-polypeptides; and amino acids (Fig. 4). ${ }^{47,50,91-98}$ R5 peptide has the amino acid sequence N-SSKKSGSYSGSKGSKRRIL-C which resembles to one of the silaffin proteins (NB. Silaffin proteins possess post-translational modifications to accommodate propylamines). Knecht and Wright prepared a range of mutant peptides wherein parts of the sequence were omitted or altered..$^{98}$ The analysis of these peptides, based on their ability to form self-assembled structures in solution and to precipitate silica, revealed that the C-terminus peptide motif was important in the peptide's activity.

Polylysine is another example which highlights the importance of physical and chemical properties of biomolecules in silica formation. Polylysine (in both L- and D-forms) has been reported to precipitate unusually structured hexagonal silica plates $\sim 50 \mathrm{~nm}$ thick and $100 \mathrm{~s} \mathrm{~nm}$ to one micron size sides, where silica was found to be amorphous (Fig. 4 and 5j). ${ }^{99-102}$ Experiments performed on polylysine to probe its secondary conformations, dynamic nature of self-assembly, crystallisation and interactions with silica species in solution revealed that in the presence of multivalent ions such as phosphate or silicate, polylysine, which is typically in an unordered (or random coil) state, rapidly transforms to a helical conformation. At a higher length scale, several helices pack together into hexagonal single crystals where the helices are arranged perpendicular to the plates (the height of helices equals the plate thickness). The hexagonal crystals of polylysine further template condensing silicates forming hexagonal silica where silica remains amorphous. This incredibly complex but very interesting facet of the polylysine-silica system has been utilised to develop responsive materials such as those that can 'switch' their morphologies. ${ }^{100,103}$ Furthermore, block-co-polypeptides from lysine and leucine have demonstrated a remarkable ability to fine tune the materials templated simply by controlling processing conditions such as nature and concentrations of counter ions, and lengths of lysine and leucine blocks. ${ }^{104}$

\subsection{Customised additives}

As a consequence of a number of investigations, some given above, rules that govern silica formation in the presence of additives have been identified and validated. Some of these rules include the necessity of the presence of specific amino acids in a peptide such as lysine; abundance of cationically charged moieties; or the importance of self-assembly of additives prior to and during silica polymerisation. In order to further probe the influence of biological and bioinspired additives on silicate species and silica polymerisation, further research had been directed towards the use of custom-made additives. These additives, which include synthetic polymers and block co-polymers, small amines and dendrimers (Fig. 4), ${ }^{47,48,57,92,94,96-99,105-138}$ had been typically wellcharacterised in terms of their chemistry and their properties readily measured. Furthermore, these tailored additives offer two important advantages: ability to probe mechanisms governing the complex process of silica formation but one at a time; and possibility of controlling properties (e.g. structure and assembly) of silicas synthesised. Since this review is focussed on key advances and applications, a comprehensive list of additives has not been provide, but a flavour of the range of additives used is presented in Fig. 4 with selected examples discussed below.

The use of customised additives has made a significant contribution to the field of bioinspired silica research and this point will be highlighted below with a range of examples of additives used and their outcomes. One group of bioextracts isolated from diatoms and sponges are linear propylamines with variable molecular size (or chain length) and levels of methylation. However, the effects of the length of these amines, the level of amine methylation, and the size of the amine spacers was unclear. Belton et al. synthesised smallamines by varying amine spacers, amine lengths and levels of methylation in order to study silica formation in the presence of these amines (Fig. 4 "small molecules"). ${ }^{57,139}$ It was reported that the balance between the charged and uncharged nitrogen atoms within a single amine molecule was crucial in silica formation. The understanding of molecular interactions between these amines and silica further allowed the controlled and rapid (within $30 \mathrm{~s}$ ) synthesis of hollow particles under mild conditions Fig. 51). ${ }^{57,140}$

We have seen in the sections above that cationically charged molecules assist silica formation under mild conditions. These molecules include amino acids such as lysine and arginine, where the interactions between anionic silicate species and ammonium or guanidinium groups from amino acids have been proposed. Coradin et al. utilised this property to design and synthesise surfactants based on arginine (Fig. 4 "small molecules"). ${ }^{108}$ These novel surfactants possessed dual features - the ability to promote silica formation and to selfassemble into templates for silica-leading to the formation of novel porous materials (see section 4.3 for the importance of porosity for silica-based materials).

Further examples can be provided of designer aminecontaining polymers and block co-polymers with a range of architectures and ability to produce self-assembled structures in solution. These include star-shaped polyethyleneimines (PEI) and copolymers of poly(2-(dimethylamino)ethyl methacrylate) polymers (Fig. 4 "synthetic polymers"). ${ }^{120,129}$ The star-shaped PEI exhibited the ability to respond to the solution processing conditions and assemble into a range of structures. When this property of PEI was exploited, Jin and Yuan were able to produce a variety of shaped-silicas including hollow nanofibres (Fig. 5k). ${ }^{119-121,124,125,128}$ Armes and co-workers 

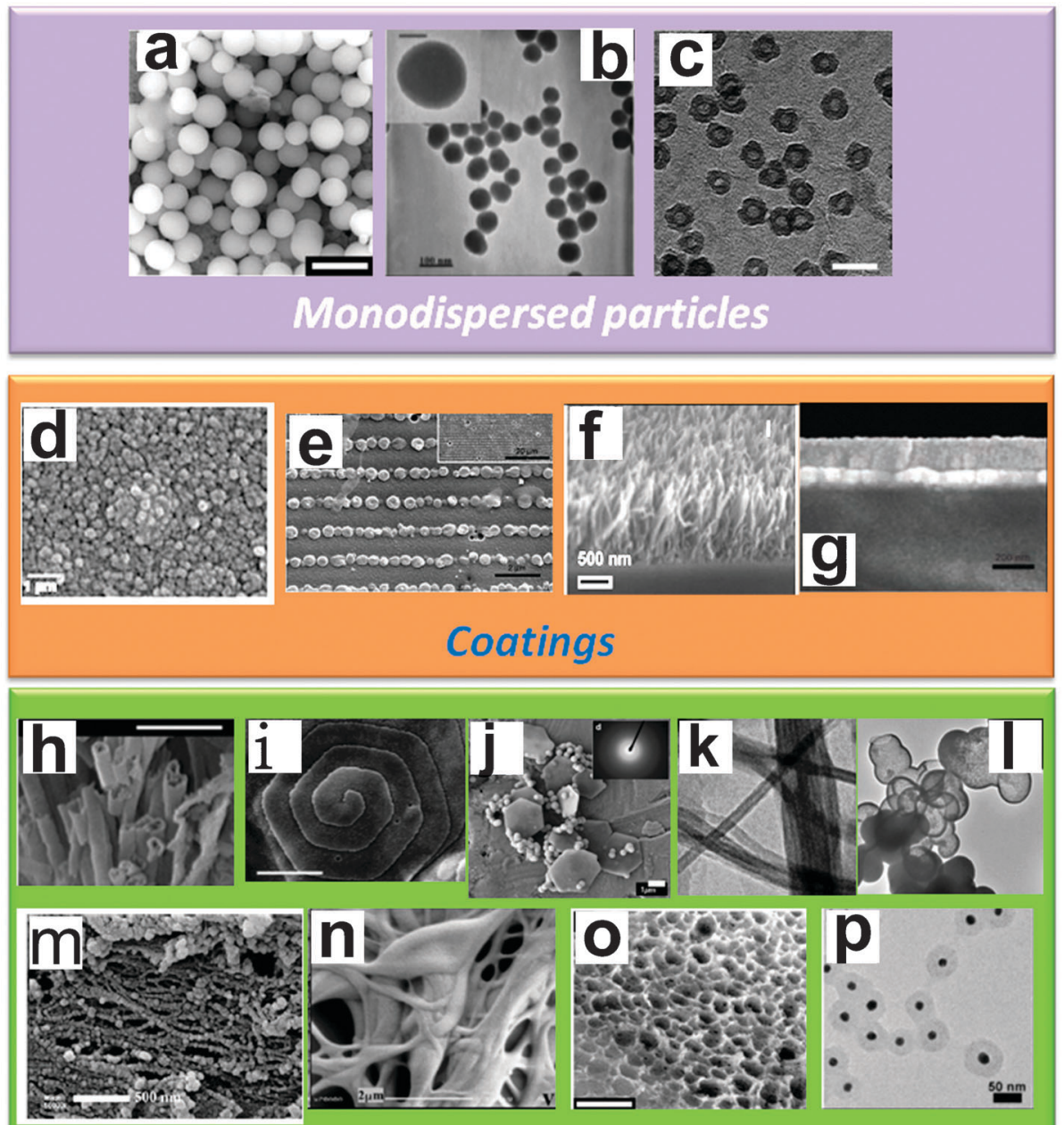

\section{Nanostructured \& Advanced Materials}

Fig. 5 Selected examples of structures and morphologies of silica that could be produced using bioinspired chemistry. These include the synthesis of monodispered particles $(\mathrm{a}-\mathrm{c})$, formation of silica coatings $(\mathrm{d}-\mathrm{g})$ and complex hybrid materials $(\mathrm{h}-\mathrm{p})$. Particulate silica formation using (a) phosphorylated silaffins, ${ }^{60}$ (b) cyclic amines ${ }^{133,136}$ and (c) diblock copolymers. ${ }^{129}$ Silica coatings produced using (d) proteins + polyamines, ${ }^{154}$ (e) R5 peptide, ${ }^{93}$ (f) polyethyleneimine (PEI) ${ }^{137}$ and (g) poly-2-(dimethylamino)ethyl methacrylate (pDMAEMA). ${ }^{116,122}$ Hollow silica tubes (h) ${ }^{246}$ and hexagonal silica nanoplates $(\mathrm{i}, \mathrm{j})^{100,103}$ formed using polylysine. Hollow nanofibres $(\mathrm{k})^{124}$ and hollow nanoparticles (l) ${ }^{140}$ using polymers and smallamines respectively. Use of biomacromolecules such as collagen $(\mathrm{m}),{ }^{247}$ chimeric silk proteins $(\mathrm{n})^{245}$ and a mixture of silaffin proteins (o) ${ }^{79}$ to produce complex hybrid materials. (p) pDMAEMA mediated AuNP@ silica. ${ }^{248}$ All the images have been reproduced with permission from the respective publishers and the original copyrights remain with the respective publishers. The original references are cited in this legend and detailed references can be found at the back of this article.

synthesised core-shell diblock polymers comprising of a pH-responsive core of poly(2-(diisopropylamino)ethyl methacrylate) and a poly(2-(dimethylamino)ethyl methacrylate) shell (Fig. 4 "synthetic polymers"). ${ }^{129}$ These core-shell polymers were highly effective in synthesising monodispersed silicapolymer hybrid particles (Fig. 5c).

We have seen a rapid growth in design of new additives which are able to control one or more aspects of silica formation including condensation rates, morphology and porosity. There are various other examples of customised additives, however, instead of listing all such molecules, their importance is provided here with the help of selected and representative examples. Some of the key benefits realised from bioinspired silica research are discussed below.

\section{Key outcomes of bioinspired silica}

Bioinspired synthesis of silica has completely changed the way scientists think of designing novel silica-based materials. The outcomes from bioinspired silica research can be summarised by discussing the ability to control materials properties and synthetic methods. In the case of amorphous silica, typically, method of synthesis, porosity, morphology and particle size are important factors which determine their properties and ultimately their use. Table 1 lists some of these properties with the nature of control possible as a consequence of bioinspired synthesis. One of the most important outcomes is the development of routes under mild synthetic conditions - all aqueous solutions, near-neutral $\mathrm{pH}$ and ambient temperature. This feature has several 
Table 1 The ability of bioinspired synthesis to fine-tune materials ${ }^{a}$

\begin{tabular}{ll}
\hline Property & Nature of control \\
\hline Condensation and growth rates & Very slow (stabilisation) - rapid (few seconds) precipitation \\
Structures \& Morphology & Particles, fibres, sheets, films, hollow tubes, porous gels, hollow particles \\
Particles size & $10 \mathrm{~s} \mathrm{~nm} \mathrm{to} \mu \mathrm{m}$ with primary particles of $2 \mathrm{~nm}-8 \mathrm{~nm}$ \\
Porosity & $0-1000 \mathrm{~m}^{2} \mathrm{~g}^{-1}$ (amorphous silica) \\
Synthetic conditions & Aqueous solutions, near-neutral pH, ambient temperature, range of precursors and concentrations \\
Composites & With peptides, proteins, enzymes, small organic molecules, drugs, polymers, QDs, catalysts, .... \\
${ }^{a}$ See text for detailed discussion and references.
\end{tabular}

implications to industrial production as well as handling sensitive materials and is discussed below.

\subsection{Ability to control silica condensation rates}

The use of a range of additives has enabled researchers to control the rates of silica condensation from very rapid instantaneous reactions to near stabilisation of silicic acids. For example, when small amines such as ethyl- or propylamines with six to seven amines were used, precipitation of spherical silica particles was evident within $30 \mathrm{~s}$ for concentrations as low as $30 \mathrm{mM}$ of silicon. ${ }^{52,57,139,141}$ When compared with silica polymerisations in the absence of any additives, early stages of silica condensation in the presence of a propylamines has been reported to be 14-times faster. ${ }^{57}$ On the other hand, certain polymeric amines such as polyvinyl imidazole, phosphonated chitosan and polyaminoamide dendrimers have been able to inhibit silica condensation completely by formation of a soluble but molybdate inactive complex (i.e. oligomers larger than trimers) between additives and silicon (in an unknown form). ${ }^{132,142,143}$ While the rapid reactions would find applications in industrial production where short residence times could be preferred, silica stabilisation has potential in water treatment and the treatment of industrial scaling and fouling caused by silicates. ${ }^{144-149}$

\subsection{Tailored materials}

The bioinspired silica research has seen the most progress in the variety of silica structures and morphologies that could be produced as a result of tailoring chemistries of additives (Table 1). Morphologies thus produced include spherical monodispersed particles, fibres, sheets, films/coatings, hollow tubes, porous gels, hollow particles and so on (Fig. 5). Monodispersed silica particles ranging from tens of $\mathrm{nm}$ to several $\mu \mathrm{m}$ sizes have been synthesised using additives such as diatom bioextracts, ${ }^{60}$ cyclic amines ${ }^{133,136,150}$ and block-copolymers (Fig. 5a-c). ${ }^{129}$ The knowledge gained from biological silica formation and in vitro model studies about silica formation in solutions ('homogeneous' systems) had been further transferred to controlling silica growth on surfaces for device fabrication (Fig. 5d-g and see section 5.2). Brott et al. have demonstrated the patterning of silica particles on a polymer to fabricate polymer-silica hologram created by two-photoninduced photopolymerisation; the material exhibited enhanced diffraction efficiency, optical performance and mechanical properties due to the presence of patterned silica particles. ${ }^{93}$ Several approaches have been successfully employed to prepare coatings of silica particles, monoliths and other structures $^{116,122,151-155}$ and their applications in fabricating sensors and devices are discussed in section 5 .

\subsection{Porosity and surface area}

Another important property of silica is its porosity (and surface area), which is essential in applications such as adsorption, catalysis, fillers and composites. Sol-gel templated synthesis has been very widely used to obtain hierarchical inorganic materials, largely silicates. ${ }^{31,33,156-159}$ Due to the flexibility, solution processing and low temperatures $\left(<100{ }^{\circ} \mathrm{C}\right)$, sol-gel method has been adapted to given synthetic conditions (e.g. solvents and precursors) and processing parameters (e.g. $\mathrm{pH}$ and temperature) to generate a range of porous and hybrid hierarchical materials including porous thin films, hybrid nanofibres, monoliths and organic-inorganic composites. ${ }^{160-164}$ High surface area $\left(>700 \mathrm{~m}^{2} \mathrm{~g}^{-1}\right)$ and high porosity silicas such as MCM- and SBA-silicas can be prepared synthetically using sol-gel processing, but only under harsh conditions and using time consuming multistep methods. ${ }^{35,36,165,166}$ The field of sol-gel derived hybrid materials has been extensively reviewed in the past. ${ }^{161-164,167}$ On the other hand, industrial precipitated silicas, which are prepared by simply neutralising sodium silicate with mineral acids, typically possess low surface areas $\left(<150 \mathrm{~m}^{2} \mathrm{~g}^{-1}\right)$ and broad pore size distribution. ${ }^{140}$ In contrast to both industrial materials and traditional sol-gel processing, bioinspired routes to produced silicas have been able to tailor the surface areas ranging from $<10$ up to $1030 \mathrm{~m}^{2} \mathrm{~g}^{-1}$ and primary pore sizes $<2$ to $60 \mathrm{~nm}$-all under mild conditions. ${ }^{48,50-52,57,108,168-170}$ For example, Coradin et al. used novel amino acid derived surfactants which produced silicas under neutral $\mathrm{pH}$ conditions with a unique bimodal distribution of pores (mesopores: 2.5-3.5 nm and meso-to-macropores: $10-100 \mathrm{~nm})$ and high surface areas $\left(>500 \mathrm{~m}^{2} \mathrm{~g}^{-1}\right) .{ }^{108}$ On the other hand, Sun and co-workers introduced polyethylene glycol (PEG) into the silica precipitating systems under acidic conditions $(\mathrm{pH} \sim 4)$. PEG samples, as a function of molecular weights, were able to produce porous silicas upon aging at $80^{\circ} \mathrm{C}$ with surface areas as high as $1030 \mathrm{~m}^{2} \mathrm{~g}^{-1}$ and pore sizes as low as $2 \mathrm{~nm}$ (or less). ${ }^{168}$ In contrast, propylamines, analogous to the amines found in diatoms and sponges, have been able to precipitate silica with surface areas $<10 \mathrm{~m}^{2} \mathrm{~g}^{-1} \cdot{ }^{51,52,57}$ It is however recognised that more progress is warranted in order to produce materials that are comparable to or better than their commercial counterparts.

\subsection{Composite/hybrid materials}

The use of sol-gel technique for synthesising organic-inorganic hybrid silicates is well known (for example see ref. 167 and 171). 
The strategies to synthesise hybrid silicates typically involve the addition of organic "dopants" to the sol-gel system or the use of organically modified silane precursors. Although a wide range of organic-inorganic composites could be envisaged by this approach, typically with hierarchical structures, it remained largely incompatible with biological materials such as cells, proteins and enzymes due to acidic conditions, highly reactive precursors and denaturation of biologicals during shrinkage of materials caused by drying. ${ }^{172}$ In order to accommodate biological samples into sol-gel materials, researchers have been developing mild routes. The state of research on bioencapsulation into silica gels, prior to the discovery of molecular secrets of biosilicification, is briefly summarised below with selected examples. Sol-gel synthesis was made compatible to biological materials by incorporating several modifications which typically include the use of customsynthesised biocompatible precursors; the addition of stabilising agents; the omission of alcohol usage; and/or the introduction of multistep procedures.

Livage and co-workers have developed methods to encapsulate whole bacterial cells into sol-gel silica matrix by utilising all-aqueous synthesis, the addition of stabilising agents such as glycerol and the replacement of alkoxysilanes precursors (which produce alcohol that can be detrimental to biological samples) with water soluble silicate. In the biocomposites, $50-60 \%$ of the entrapped cells were preserved for up to one month in wet gels. ${ }^{173-178}$ Another modification to sol-gel synthesis for rendering biocompatibility involves a two step process: ${ }^{179-183}$ in the first step, an alkoxysilane is hydrolysed under acidic conditions to produce a sol. Typically in this step, the use of alcohol is avoided, however, it has been reported that any alcohol added or produced during the hydrolysis can be subsequently removed. ${ }^{184}$ In the second step, the sol is added to a buffered solution of biological samples (e.g. enzymes or cells) thereby maintaining the $\mathrm{pH}$ and the aqueous conditions that are necessary to avoid deactivation of biological materials. Furthermore, several research groups reported the preparation of silica gels with immobilised enzymes by the introduction of either stabilising agents such as carbohydrates, glycol or amino acids, or using biocompatible organically modified silane precursors. ${ }^{181,185,186}$

The aforementioned approaches provide a substantial improvement to the traditional sol-gel synthesis and therefore they have been widely used to immobilise enzymes and cells. However, these modified sol-gel methods still suffer from long gelation times of several hours to weeks; ${ }^{185}$ high silicate concentrations; ${ }^{180}$ tedious multistep procedures; ${ }^{182,184}$ and the requirement of custom-synthesised biocompatible precursors. ${ }^{186}$

Mild synthetic conditions of bioinspired silica formation have allowed the formation of composite/hybrid materials of silica with peptides, proteins, enzymes, small organic molecules, drugs, polymers, quantum dots, catalysts nanoparticles, and the list continues (for selected examples see Fig. $5 \mathrm{~h}-\mathrm{p}$ ). ${ }^{187-193}$ This ability, perhaps, will emerge as one of the largest advantages of bioinspired silica synthesis when one considers potential applications (discussed in detail in section 5).

Before we close this section and focus on the applications developed from bioinspired synthesis, the readers are made aware of a few issues. In order to understand and control bioinspired synthesis, in depth knowledge of silica condensation and speciation is required. It should be remembered that simply changing the silica precursor can affect the system tremendously which has been highlighted in a recent study; ${ }^{58}$ the report also identifies the silicate species present at a given time in the early stages of silica condensation. Furthermore, synthetic and analytical parameters should be very carefully chosen which include the use of buffers, presence of electrolytes, purity of additives, concentrations of $\mathrm{Si}$ and additives, and analytical techniques used. Each of these factors can greatly affect silica formation and therefore may also influence the conclusions drawn. ${ }^{1}$

The solubility of silica and silicates, measured as the concentration of orthosilicic acid, has been reported to occur at $5.2-15.6 \mu \mathrm{M}$ in sea water and $5.2-36.4 \mu \mathrm{M}$ in fresh water. $^{6,32,194}$ The condensation of orthosilicic acid, sometimes termed autopolymerisation, generally occurs at concentrations $>2 \mathrm{mM}$, thus suggesting that the natural waters are highly undersaturated. However, biosilicifying organisms accumulate orthosilicic acid from their environment that is vastly undersaturated with respect to silicon and form sophisticated nanopatterned organic-inorganic silica-based composites. In contrast, in vitro silica precipitation studies, which typically operate under supersaturated concentrations of orthosilicic acid (typically $30 \mathrm{mM}$ or $100 \mathrm{mM}$ ), have failed to produce silica from undersaturated solutions. ${ }^{150}$ Although biosilica and silica formation from undersaturated solutions remains open for further investigations, the enigmatic nature of biosilicification perhaps makes it more intriguing.

\section{Applications}

The development of applications arising from biosilicification and bioinspired silica has been slower than perhaps expected. One of the reasons could be the amount of groundwork required for building important and fundamental understanding of silica-biomolecule systems. We have discussed some of the main outcomes of these studies above and it is believed that we now have a toolbox for developing novel materials and applications. Although progress has been slow, there have been a range of applications already demonstrated in the areas of sensors, coatings, catalysis and biocatalysis, drug delivery, hybrid materials and scale-up (Fig. 2, lower section). With selected examples, we set out to explain and discuss how the understanding of biological and bioinspired silica formation has been successfully transferred. It should be noted that the direct use of biosilica and biosilicifying systems for applications is out of the scope of this review and readers are directed to the appropriate literature. ${ }^{13,21,195-198}$

\subsection{Biocatalysis and drug delivery}

Luckarift et al. utilised the ability of a peptide (R5) derived from diatoms to form silica under mild conditions and developed a one-pot, one-step synthesis of silica-enzyme composites. ${ }^{187}$ This method was used to immobilise butyrylcholinesterase onto silica where superior performance, up to $90 \%$ immobilisation efficiency and high loading ( $\sim 20 \mathrm{wt} \%)$ was achieved (Fig. 6a). The co-precipitation of enzyme and 

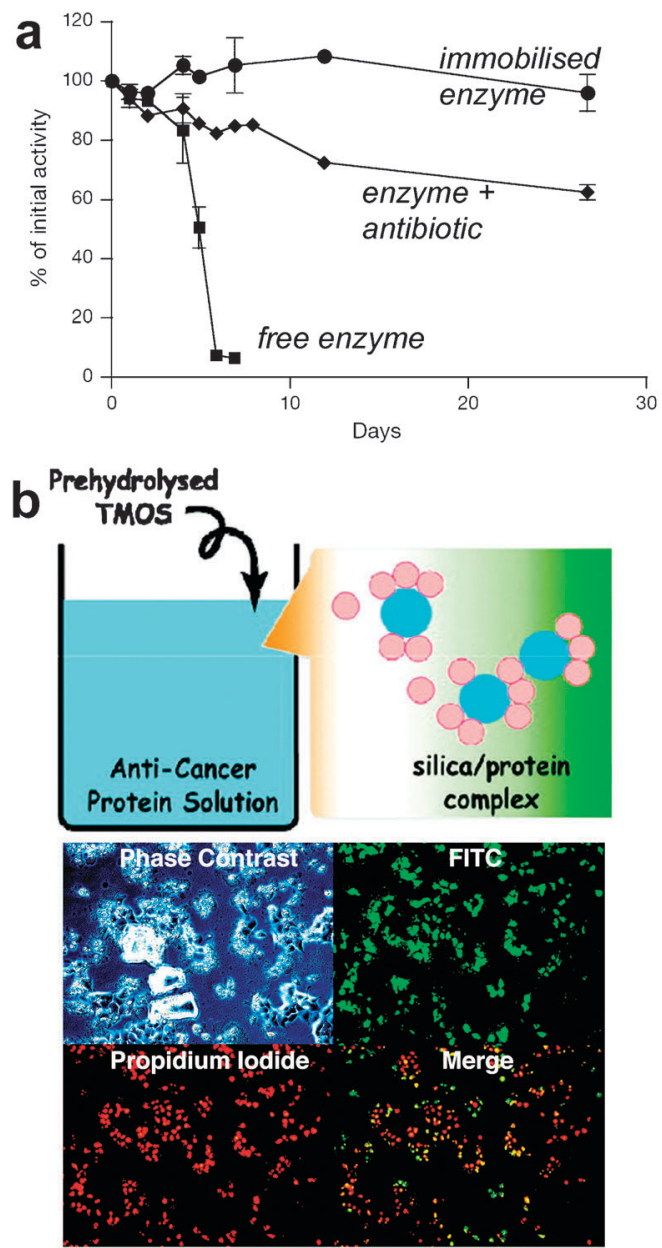

Fig. 6 Examples of bioinspired silica in applications such as biocatalysis and drug delivery. (a) Comparison of free butyrylcholinesterase with that immobilised on silica using R5 peptide mediated co-precipitation of enzyme and silica. (b) The use of a bifunctional anticancer silica forming protein to formulate a drug delivery system (high resolution image kindly provided by Dr Sano). Images are copyright of Nature Publishing Group (a) and the American Chemical Society (b) and are reproduced with permission of Nature Publishing Group from ref. 187 and the American Chemical Society from ref. 193.

silica imparted high thermal stability to the enzyme and substantially reduced enzyme leaching. As noted in section 4.4 above, prior to the advent of bioinspired silica, enzyme encapsulation/immobilisation onto silica under all-aqueous conditions, room temperature and without the need of speciality reagents had rarely been possible. Recently, Sun et al. elegantly demonstrated cascade reactions for converting carbon dioxide to methanol in three steps using a combination of three dehydrogenases co-immobilised. ${ }^{191}$ When compared with free dehydrogenases, the co-immobilised system exhibited higher yield, improved thermal and chemical stability, greater shelf-life and ability to reuse. It was further demonstrated that bioinspired silica technology was suitable for many enzymes, particularly sensitive enzymes, and a variety of reactor configurations such as fluidised bed, microfluidic devices or packed bed could be employed. ${ }^{187,188,190,192,199-205}$

There have been further efforts to encapsulate biologically relevant materials into bioinspired silica such as fluorescent dyes, model drug molecules or antimicrobial agents. ${ }^{125,206-208}$ Sano et al. have reported the development of an anticancer drug delivery system using a bioinspired silica technique. ${ }^{193}$ A protein was designed which possessed dual functionalitiessilica precipitation ability and anticancer activity - and it was used to polymerise silica thereby immobilising itself on to silica (Fig. 6b). In aqueous solutions, silica was found to hydrolyse and slowly release the anticancer protein causing cancer cell death. This example highlighted the importance of the ability to control silica condensation (also discussed in section 4), which has proven to be critical in developing applications where, for example, silica needs to hydrolyse to release drug or it needs to be highly cross-linked to avoid any leaching of enzymes in biocatalysis.

\subsection{Sensors}

A second set of applications discussed here is the preparation of sensors using a bioinspired silica technology. ${ }^{208-212}$ Millner, Chaniotakis and their respective co-workers have fabricated electrochemical biosensors using carbon nanofibres (CNF) or metallic electrodes containing silica-enzyme coatings deposited using bioinspired method (Fig. 7a). ${ }^{209-213}$ Acetylcholinesterase (AChE) was immobilised on electrodes, which catalyses the formation of acetic acid and thiocholine (TCh) from acetylthiocholine (ATCh); the reaction can be monitored by detecting an increase in anodic current upon the oxidisation of thiocholine on the electrode. It was reported that, in addition to improved operational life, thermal stability and protection against protease attack, the CNF-AChE-silica biosensor system demonstrated a linear response over a wider range, greater sensitivity and faster response when compared with silica-enzyme system without the CNF (Fig. 7b). ${ }^{211}$

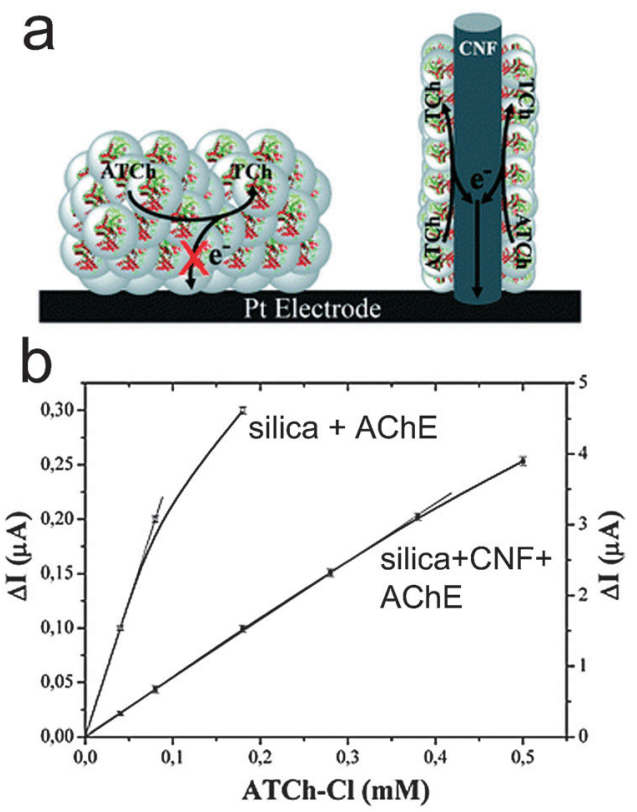

Fig. 7 Electrochemical sensors fabricated using bioinspired silica technology to stabilise enzymes and carbon nanofibres onto metallic electrodes. Images are copyright of the Royal Society of Chemistry and are reproduced with permission of the Royal Society of Chemistry from ref. 211. 


\subsection{Supporting metals and functional metallic nanoparticles}

Supported metallic particles on silica and other ceramic matrices have been widely used for applications such as metal-catalysed reactions, molecular electronics, optically active materials, sensors, etc. Bioinspired methods have been used to synthesise metallic, metal oxide and bimetallic nanoparticles supported on silica. ${ }^{114,188,192,213}$ Dendrimer or peptide mediated silica formation was adopted for the encapsulation of quantum dots of $\mathrm{CdSe}-\mathrm{ZnS}$ and it was found that even upon encapsulation in silica, the quantum dots retained their optical activity (Fig. 8a). ${ }^{114,188}$ Similarly, silicagold nanoparticle composites were prepared using dendrimers or small amines where the gold nanoparticles remained active (Fig. 8b). ${ }^{14,192}$ Furthermore, enzyme-iron oxide-silica hybrid particles were synthesised - the enzyme was used for catalysing reactions while the iron oxide particles proved valuable for magnetically separating hybrid particles upon completion of the reaction for reuse. ${ }^{188}$

O'Leary et al. prepared metallic catalysts supported on silica by starting with silane functionalised pincer-metal complexes (Fig. 8c). ${ }^{214}$ These complexes were condensed with an alkoxysilane in the presence of silicatein protein to produce metalsilica composites which demonstrated applications in sensors and catalysis. Pt-silica prepared using this method were used for $\mathrm{SO}_{2}$ sensing while Pd-silica hybrids were successfully tested for Heck reactions for carbon-carbon coupling. ${ }^{214}$

\subsection{Non-silicates}

Research on bioinspired silica has also produced insights for synthesis and fabrication of non-silicates such as ceramic,

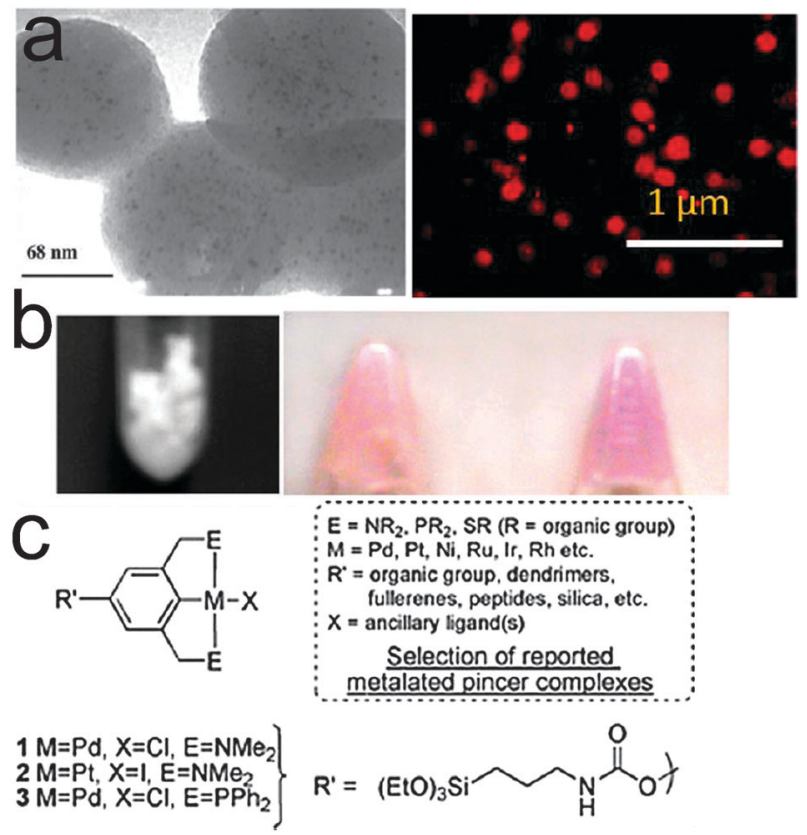

Fig. 8 Bioinspired silica synthesis applied for supporting metals and functional metallic nanoparticles such as $\mathrm{CdSe}-\mathrm{ZnS}$ quantum dots (a), gold nanoparticles (b) and organometallic compounds (c). Images reproduced with permission of (a) the American Chemical Society from ref. 114, (b) Springer from ref. 192 and (c) the Royal Society of Chemistry from ref. 214. Images are copyright of respective publishers. metallic and bimetallic materials which are extremely valuable in commercial applications in areas such as devices and sensors fabrication, catalysts, cosmetics, electronics, optically active materials, etc. This has been a key advancement especially for producing materials from non-biological elements including germanium, ${ }^{117,215-218}$ titanium, ${ }^{134,137,191,206,218-226}$ gallium, ${ }^{227}$ barium, ${ }^{228}$ zinc, $^{229}$ platinum, ${ }^{230}$ zirconium $^{220,231}$ and copper ${ }^{230}$ where direct examples of nanomaterial formation using biomolecules is not available. ${ }^{19}$ Although an excellent review already exists on "Protein- and Peptide-Directed Syntheses of Inorganic Materials", ${ }^{232}$ due to the importance of these systems, some examples are given below.

The biosilica forming silicatein proteins extracted from sponges have successfully produced titania $\left(\mathrm{TiO}_{2}\right)$ and zirconia $\left(\mathrm{ZrO}_{2}\right)$ under mild conditions. ${ }^{19,219,220,222,227}$ The catalytic and templating effects of silicatein were apparent when in the absence of silicatein, oxide formation required high temperatures or alkali. It was reported that silicatein mediated titania formation showed a delayed phase transition from anatase to rutile under thermal treatment. Furthermore, designer recombinant proteins based on the sequence of silaffin proteins isolated from diatoms or other well-known proteins have demonstrated the ability to produce non-silicates. ${ }^{56,117,233,234}$ Kröger et al. reported that such novel proteins were able to catalyse the formation of oriented rutile microcrystals under mild conditions of temperature and $\mathrm{pH}$ (Fig. 9a). ${ }^{223}$ As noted already, since the formation of rutile requires extreme conditions of temperature or $\mathrm{pH}$, the advantages of bioinspired techniques for the synthesis of nano- and microcrystalline titania are clearly highlighted, especially when considering its applications in photocatalysis, photovoltaics, gas sensing, and pigments.

A synthetic polymer-polyallylamine - which has been demonstrated to control silica formation in vitro under mild conditions, had been reported to precipitate spherical and elongated germania particle-all under neutral $\mathrm{pH}$ and in aqueous systems (Fig. 9b). ${ }^{215}$ Taking into account the potential commercial applications of germania-based materials in fibre optics, waveguides, optoelectronic devices and complementary metal-oxide semiconductors (CMOS), the bioinspired route to germania is highly important.
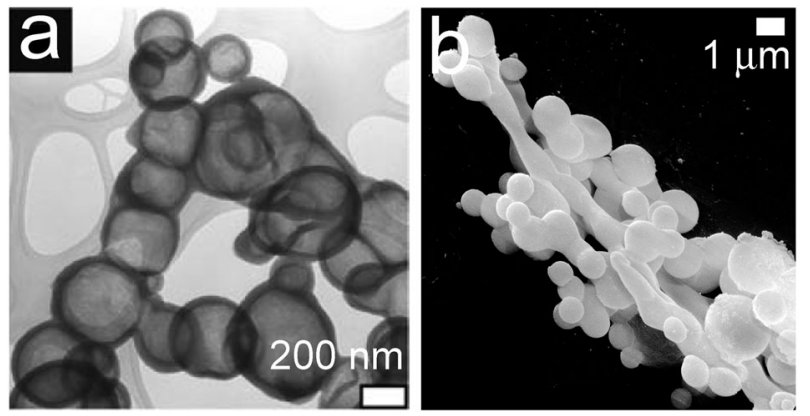

Fig. 9 (a) Recombinant proteins inspired from silaffins produce oriented rutile microcrystals at room temperature. ${ }^{223}$ (b) Synthesis of anisotropic germania particles using a bioinspired synthetic polymer. $^{215}$ Images reproduced with permission of Wiley (a) and Elsevier (b) from ref. 223 and 215 respectively. Images remain copyright of respective publishers. 
Slocik and Wright further broadened the bioinspired synthesis by demonstrating the ability of amino acids and small peptides to nucleate and stabilise a range of zero-valent metallic nanoparticles. ${ }^{230}$ These examples clearly demonstrate the importance of transferring knowledge gained of the chemistry of bioinspired silica.

\subsection{Scale-up and process intensification}

Recognising the benefits of the newly invented bioinspired synthesis of nanomaterials, one could appreciate the savings and reduction in waste production upon realisation of these methods on an industrial scale. In order to establish the viability for an industrial-scale production of nanomterials, scale-up (often jokingly referred to as "bucket chemistry") and/or process intesification of the bioinspired synthesis is crucial. ${ }^{235}$ The core aspects of the chemistry of bioinspired synthesis of silica such as reagents, catalysts (or additives) and conditions have been extensively studied and results reported in the literature. ${ }^{50-52,57-59,112,236}$ Bioinspired synthesis of nanomaterials is currently essentially a batch scale method producing $\mu \mathrm{g}$ to $\mathrm{mg}$ quantities. In order to commercialise this method, process engineers need to identify and optimise practical ways and equipment configurations. ${ }^{237}$ It is noted that scaling-up a bench-top reaction is often not trivial for reasons such as non-linear scaling of laws governing transport phenomena as well as surface area to volume ratios. ${ }^{237,238}$ Furthermore, heterogeneous reactions (e.g. nanoparticle production) and most unit operations are scale-dependent. ${ }^{239}$ In other words, "chemical rate constants are scale independent, but physical parameters are not." 240

While scaling-up, a choice between batch or continuous production has to be made. Batch processes are easy to design from bench-scale reactions, and are versatile and flexible. The ease of scale-up using batch processing has been recently demonstrated in two examples of bioinspired materials synthesis. In a recent conference, McAuliffe et al. reported a scalable method for multi-gram scale production of enzyme supported on silica using polyethyleneimine. ${ }^{241}$ Morse and co-workers applied the principles of bioinspired synthesis to the low temperature $\left(16-80{ }^{\circ} \mathrm{C}\right)$ production of $\mathrm{BaTiO}_{3}$ in a 2 litre reactor (reaction time $=24 \mathrm{~h}$ to $10 \mathrm{~d}$ ), where up to $250 \mathrm{~g}$ of nanomaterial could be produced (Fig. 10a). ${ }^{242}$

It is known that batch processes pose difficulties in process integration, suffer from low capacities, high capital costs and high down-times. Continuous processing, on the other hand, provides cheaper alternative and high capacities. ${ }^{240}$ The scale-up of bioinspired silica synthesis was successfully demonstrated using a continuous flow tubular (a plug-flow type) reactor (Fig. 10b). ${ }^{192}$ This process displayed versatility when silica production was tested with a range of additives and processing conditions (reagent concentrations, reaction times and flow rates). Furthermore, the suitability of this approach for the preparation of functional hybrid nanomaterials was evident from the reported examples of quantum dots encapsulation or enzyme immobilisation. ${ }^{192}$ While the scale-up is currently only limited to selected materials such as silica and $\mathrm{BaTiO}_{3},{ }^{192,242,243}$ in view of the advances in bioinspired synthesis of other nanomaterials ${ }^{232}$ and the progress made in

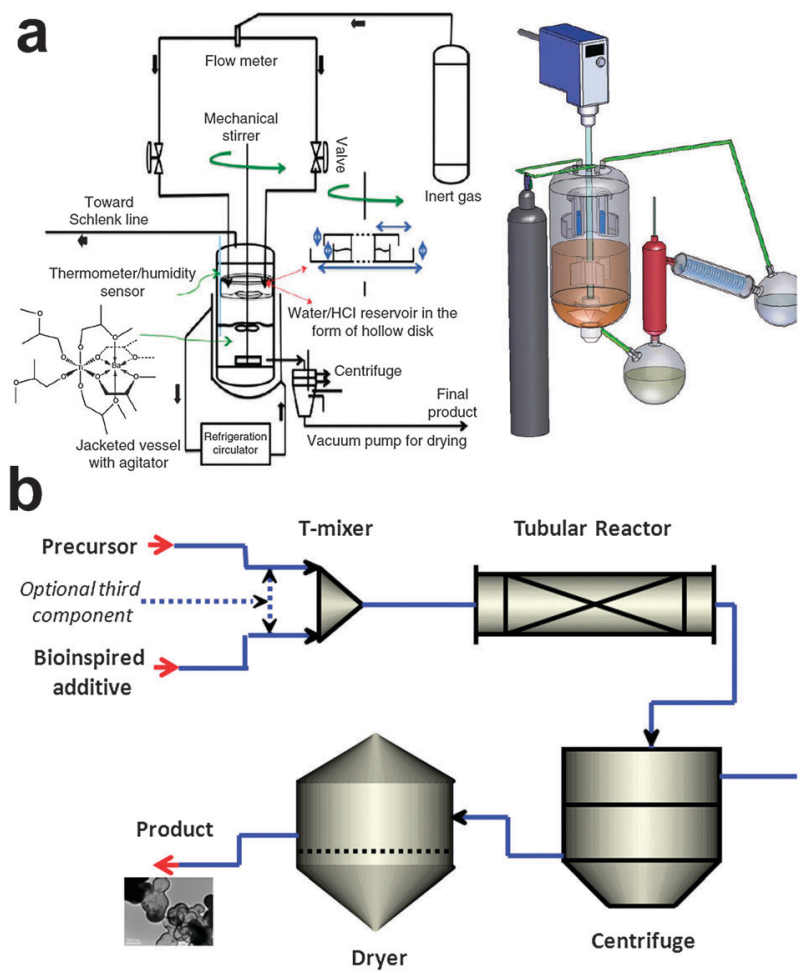

Fig. 10 (a) Process flow diagram (PFD) (left) and pictorial overview (right) of a large scale batch production of $\mathrm{BaTiO}_{3}$. (b) A PFD of continuous silica production. Images reproduced from (a) ref. 242 and (b) adopted from ref. 192 with permission from Nature Publishing Group and Springer respectively. Images are copyright of respective publishers.

continuous production of nanomaterials from non-bioinspired methods (see ref. $1-10$ in ref. 192), it is only a matter of time before we witness the scale-up of a range of functional materials.

\section{Summary}

Through various strategies, researchers have found ways to transfer the biological secrets into synthetic approaches to invent bioinspired silica technology (Fig. 11). Without the advent of bioinspired silica synthesis, rapid and controlled synthesis of silicas under mild conditions and without the need of non-aqueous co-solvents had been rarely possible. It can be appreciated that some of the important features of biosilicification have been realised in bioinspired synthesis which include mild conditions and green synthesis, tailoring materials properties, and the ability to encapsulate foreign materials. Such control has been only possible due to the tremendous progress in the groundwork required for building fundamental understanding of silica-biomolecule systems as seen in the last decade.

More importantly, applications in areas ranging from biomedical materials to sensors and composite materials have started to appear. Perhaps more exciting is the use of biosilicification knowledge to manipulate biological silica formation or to develop non-silicate materials from non-biological elements for applications in optical and electronic materials. 


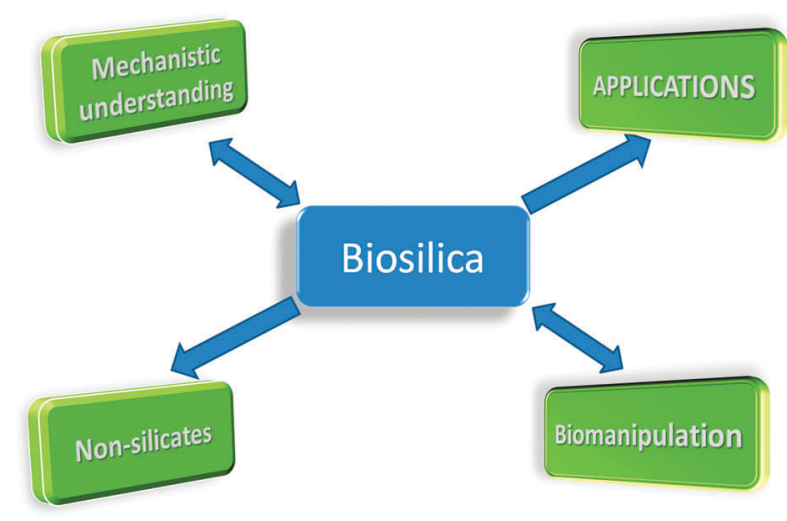

Fig. 11 A schematic overview of how biosilica research relates to generating molecular understanding, novel materials, applications and ideas for manipulation of biosilicifying systems.

Scientists have started taking strides towards scaling-up this technology to enable it for industrial manufacturing.

One could argue that learning from biology, 'green' routes to silica have been invented. If these advances are implemented in current industrial production of silica, large savings, in addition to better control, could be achieved. Without any doubts, the future of bioinspired silica research will be in demonstrating the versatility of this technology for generating applications that can make a significant impact.

\section{Acknowledgements}

The editors are thanked for an invitation to write this review. The financial support was provided by the Royal Society (TG092480), the Department of Chemical and Process Engineering and the Faculty of Engineering, University of Strathclyde. The author expresses his gratitude towards the invaluable inputs by Professor Stephen J. Clarson and Professor Carole C. Perry over a number of years. Colleagues and collaborators are thanked for helpful discussions including Dr Kristi Kiick, Dr D. J. Belton, Dr K.-I. Sano and Dr G. Beaucage. Critical comments on the drafts of this manuscript by Dr H. A. Currie are greatly appreciated. Referees are thanked for providing constructive comments and suggestions which have improved this article substantially.

\section{Notes and references}

1 S. V. Patwardhan, S. J. Clarson and C. C. Perry, Chem. Commun., 2005, 1113-1121.

2 World market for Precipitated Silica, Notch Consulting Group, 2006.

3 M. Pagliaro, Silica-Based Materials for Advanced Chemical Applications, RSC Publishing, Cambridge, 2009.

4 O. W. Flörke, H. A. Graetsch, F. Brunk, L. Benda, S. Paschen, H. E. Bergna, W. O. Roberts, W. A. Welsh, C. Libanati, M. Ettlinger, D. Kerner, M. Maier, W. Meon, R. Schmoll, H. Gies and D. Schiffmann, in Ullmann's Encyclopedia of Industrial Chemistry, Wiley-VCH Verlag GmbH \& Co. KGaA, 2000.

5 R. Tacke, Angew. Chem., Int. Ed., 1999, 38, 3015-3018.

6 P. Treguer, D. M. Nelson, A. J. Vanbennekom, D. J. Demaster, A. Leynaert and B. Queguiner, Science, 1995, 268, 375-379.

7 Biomineralization: from biology to biotechnology and medical application, ed. E. Baeuerlein, Wiley-VCH, Chichester, 2000.
8 H. A. Lowenstam and S. Weiner, On Biomineralization, Oxford University Press, New York, 1989.

9 S. Mann, Biomineralization: Principles and Concepts in Bioinorganic Materials Chemistry, Oxford University Press, New York, 2001.

10 Biomineralization, ed. S. Mann, J. Webb and R. J. P. Williams, VCH, Weinheim, 1989.

11 C. Sanchez, H. Arribart and M. M. G. Guille, Nat. Mater., 2005, 4, 277-288.

12 C. Exley, in Biosilica in Evolution, Morphogenesis, and Nanobiotechnology: Case Study Lake Baikal, ed. W. E. G. Müller and M. A. Grachev, Springer, Berlin, 2009, vol. 47.

13 M. Hildebrand, Chem. Rev., 2008, 108, 4855-4874.

14 M. Hildebrand and R. Wetherbee, Prog. Mol. Subcell. Biol., 2003, 33, 11-57.

15 Silicon and Siliceous Structures in Biological Systems, ed. T. L. Simpson and B. E. Volcani, Springer-Verlag, New York, 1981.

16 C. C. Perry and T. Keeling-Tucker, J. Biol. Inorg. Chem., 2000, 5, $537-550$.

17 Silicon Biomineralization, ed. W. E. G. Müller, Springer, Berlin, 2003.

18 Biosilica in Evolution, Morphogenesis, and Nanobiotechnology: Case Study Lake Baikal, ed. W. E. G. Müller and M. A. Grachev, Springer, Berlin, 2009, vol. 47.

19 R. L. Brutchey and D. E. Morse, Chem. Rev., 2008, 108, 4915-4934.

20 M. Sumper and E. Brunner, Adv. Funct. Mater., 2006, 16, 17-26.

21 W. Yang, P. J. Lopez and G. Rosengarten, Analyst, 2011, 136, $42-53$.

22 H. A. Currie, S. V. Patwardhan, C. C. Perry, P. Roach and N. J. Shirtcliffe, in Hybrid materials -Synthesis, characterization and Applications, ed. G. Kickelbick, Wiley-VCH, Weinheim, 2007, pp. 255-299.

23 J. F. Ma, Prog. Mol. Subcell. Biol., 2003, 33, 127-147.

24 J. Aizenberg, V. C. Sundar, A. D. Yablon, J. C. Weaver and G. Chen, Proc. Natl. Acad. Sci. U. S. A., 2004, 101, 3358-3363.

25 J. Aizenberg, J. C. Weaver, M. S. Thanawala, V. C. Sundar, D. E. Morse and P. Fratzl, Science, 2005, 309, 275-278.

26 V. C. Sundar, A. D. Yablon, J. L. Grazul, M. Ilan and J. Aizenberg, Nature, 2003, 424, 899-900.

27 C. C. Perry, in Biomineralisation, Chemical and Biochemical Perspectives, ed. S. Mann, J. Webb and R. J. P. Williams, VCH, 1989, pp. 223-257.

28 E. G. Vrieling, T. P. M. Beelen, Q. Y. Sun, S. Hazelaar, R. A. van Santen and W. W. C. Gieskes, J. Mater. Chem., 2004, 14, 1970-1975.

29 F. E. Round, R. M. Crawford and D. G. Mann, The Diatoms: Biology \& Morphology of the Genera, Cambridge University Press, Cambridge, 1990.

30 E. G. Vrieling, W. W. C. Gieskes and T. P. M. Beelen, J. Phycol., 1999, 35, 548.

31 C. J. Brinker and G. W. Scherer, Sol-Gel Science: The Physics and Chemistry of Sol-Gel Processing, Academic Press, Boston, 1990.

32 R. K. Iler, The Chemistry of Silica, John Wiley \& Sons, New York, 1979.

33 L. L. Hench and J. K. West, Chem. Rev., 1990, 90, 33-72.

34 C. T. Kresge, M. E. Leonowicz, W. J. Roth, J. C. Vartuli and J. S. Beck, Nature, 1992, 359, 710-712.

35 Q. Huo, D. I. Margolese and G. D. Stucky, Chem. Mater., 1996, 8, $1147-1160$.

36 D. Y. Zhao, J. L. Feng, Q. S. Huo, N. Melosh, G. H. Fredrickson, B. F. Chmelka and G. D. Stucky, Science, 1998, 279, 548-552.

37 M. J. Ellwood, M. Wille and W. Maher, Science, 2010, 330, 1088-1091.

38 C. F. van der Walle, Silicon, 2011, 3, DOI: 10.1007/s12633-1201119071.

39 M. Hildebrand, in Biomineralization: From Biology to Biotechnology and Medical Application, ed. E. Baeuerlein, Wiley, Weinheim, 2000, pp. 171-188.

40 M. Hildebrand, B. E. Volcani, W. Gassmann and J. I. Schroeder, Nature, 1997, 385, 688-689.

41 J. F. Ma, K. Tamai, N. Yamaji, N. Mitani, S. Konishi, M. Katsuhara, M. Ishiguro, Y. Murata and M. Yano, Nature, 2006, 440, 688-691. 
42 N. Kröger, R. Deutzmann, C. Bergsdorf and M. Sumper, Proc. Natl. Acad. Sci. U. S. A., 2000, 97, 14133-14138.

43 S. Matsunaga, R. Sakai, M. Jimbo and H. Kamiya, ChemBioChem, 2007, 8, 1729-1735.

44 K. Shimizu, J. Cha, G. D. Stucky and D. E. Morse, Proc. Natl. Acad. Sci. U. S. A., 1998, 95, 6234-6238.

45 A. Krasko, B. Lorenz, R. Batel, H. C. Schröder, I. M. Müller and W. E. G. Müller, Eur. J. Biochem., 2001, 267, 4878-4887.

46 W. E. G. Müller, A. Krasko, G. Le Pennec, R. Steffen, M. S. A. Ammar, M. Wiens, I. M. Müller and H. C. Schröder, Prog. Mol. Subcell. Biol., 2003, 33, 122-195.

47 T. Coradin and J. Livage, Colloids Surf., B, 2001, 21, 329-336.

48 T. Coradin, O. Durupthy and J. Livage, Langmuir, 2002, 18, 2331-2336.

49 T. Coradin, A. Coupe and J. Livage, Colloids Surf., B, 2003, 29, 189-196.

50 D. Belton, G. Paine, S.V. Patwardhan and C. C. Perry, J. Mater. Chem., 2004, 14, 2231-2241.

51 D. Belton, S. V. Patwardhan and C. C. Perry, Chem. Commun., 2005, 3475-3477.

52 D. J. Belton, S. V. Patwardhan and C. C. Perry, J. Mater. Chem., $2005,15,4629-4638$.

53 S. V. Patwardhan, D. Belton, G. Tilburey and C. C. Perry, in Advances in Silicones and Silicone-Modified Materials, eds. S. J. Clarson, M. J. Owen, S. D. Smith and M. E. V. Dyke, American Chemical Society, Washington, DC, 2010, pp 229-240.

54 S. V. Patwardhan, G. Patwardhan and C. C. Perry, J. Mater. Chem., 2007, 17, 2875-2884.

55 S. V. Patwardhan, K. Shiba, H. C. Schroder, W. E. G. Muller, S. J. Clarson and C. C. Perry, in The Science and Technology of Silicones and Silicone-Modified Materials, ed. S. J. Clarson, J. J. Fitzgerald, M. J. Owen, S. D. Smith and M. E. Van Dyke, American Chemical Society, 2007, vol. 964.

56 S. V. Patwardhan, K. Shiba, H. C. Schroder, W. E. G. Muller, S. J. Clarson and C. C. Perry, in Science and Technology of Silicones and Silicone-Modified Materials, ed. S. J. Clarson, J. J. Fitzgerald, M. J. Owen, S. D. Smith and M. E. VanDyke, 2007, vol. 964, pp. 328-347.

57 D. J. Belton, S. V. Patwardhan, V. V. Annenkov, E. N. Danilovtseva and C. C. Perry, Proc. Natl. Acad. Sci. U. S. A., 2008, 105, 5963-5968.

58 D. J. Belton, O. Deschaume, S. V. Patwardhan and C. C. Perry, J. Phys. Chem. B, 2010, 114, 9947-9955.

59 C. Groeger, K. Lutz and E. Brunner, Cell Biochem. Biophys., $2008, \mathbf{5 0}, 23-39$.

60 N. Kröger, S. Lorenz, E. Brunner and M. Sumper, Science, 2002, 298, 584-586.

61 R. Gordon and R. W. Drum, Int. Rev. Cytol., 1994, 150, 243.

62 T. Coradin and P. J. Lopez, ChemBioChem, 2003, 4, 251-259.

63 T. Coradin, P. J. Lopez, C. Gautier and J. Livage, C. R. Palevol, 2004, 3, 443-452.

64 M. A. Brook, Silicon in Organic, Organometallic, and Polymer Chemistry, John Wiley \& Sons, New York, 2000, 459-462.

65 Silicon Biochemistry, ed. D. Evered and M. O'Connor, Wiley, New York, 1986.

66 C. C. Perry, in Biosilica in Evolution, Morphogenesis, and Nanobiotechnology: Case Study Lake Baikal, ed. W. E. G. Müller and M. A. Grachev, Springer, Berlin, 2009, vol. 47, pp. 295-313.

67 C. C. Harrison, Phytochemistry, 1996, 41, 37-42.

68 N. Kröger, G. Lehmann, R. Rachel and M. Sumper, Eur. J. Biochem., 1997, 250, 99-105.

69 C. C. Perry and T. Keeling-Tucker, Colloid Polym. Sci., 2003, 281, 652-664.

70 L. G. Frigeri, T. R. Radabaugh, P. A. Haynes and M. Hildebrand, Mol. Cell. Proteomics, 2006, 5, 182-193.

71 N. Kroger and N. Poulsen, Annu. Rev. Genet., 2008, 42, 83-107.

72 H. Ehrlich, R. Deutzmann, E. Brunner, E. Cappellini, H. Koon, C. Solazzo, Y. Yang, D. Ashford, J. Thomas-Oates, M. Lubeck, C. Baessmann, T. Langrock, R. Hoffmann, G. Wörheide, J. Reitner, P. Simon, M. Tsurkan, A. V. Ereskovsky, D. Kurek, V. V. Bazhenov, S. Hunoldt, M. Mertig, D. V. Vyalikh, S. L. Molodtsov, K. Kummer, H. Worch, V. Smetacek and M. J. Collins, Nat. Chem., 2010, 2, 1084-1088.

73 E. V. Armbrust, J. A. Berges, C. Bowler, B. R. Green, D. Martinez, N. H. Putnam, S. G. Zhou, A. E. Allen,
K. E. Apt, M. Bechner, M. A. Brzezinski, B. K. Chaal, A. Chiovitti, A. K. Davis, M. S. Demarest, J. C. Detter, T. Glavina, D. Goodstein, M. Z. Hadi, U. Hellsten, M. Hildebrand, B. D. Jenkins, J. Jurka, V. V. Kapitonov, N. Kroger, W. W. Y. Lau, T. W. Lane, F. W. Larimer, J. C. Lippmeier, S. Lucas, M. Medina, A. Montsant, M. Obornik, M. S. Parker, B. Palenik, G. J. Pazour, P. M. Richardson, T. A. Rynearson, M. A. Saito, D. C. Schwartz, K. Thamatrakoln, K. Valentin, A. Vardi, F. P. Wilkerson and D. S. Rokhsar, Science, 2004, 306, 79-86.

74 C. Bowler, A. E. Allen, J. H. Badger, J. Grimwood, K. Jabbari, A. Kuo, U. Maheswari, C. Martens, F. Maumus, R. P. Otillar, E. Rayko, A. Salamov, K. Vandepoele, B. Beszteri, A. Gruber, M. Heijde, M. Katinka, T. Mock, K. Valentin, F. Verret, J. A. Berges, C. Brownlee, J. P. Cadoret, A. Chiovitti, C. J. Choi, S. Coesel, A. De Martino, J. C. Detter, C. Durkin, A. Falciatore, J. Fournet, M. Haruta, M. J. J. Huysman, B. D. Jenkins, K. Jiroutova, R. E. Jorgensen, Y. Joubert, A. Kaplan, N. Kroger, P. G. Kroth, J. La Roche, E. Lindquist, M. Lommer, V. Martin-Jezequel, P. J. Lopez, S. Lucas, M. Mangogna, K. McGinnis, L. K. Medlin, A. Montsant, M. P. Oudot-Le Secq, C. Napoli, M. Obornik, M. S. Parker, J. L. Petit, B. M. Porcel, N. Poulsen, M. Robison, L. Rychlewski, T. A. Rynearson, J. Schmutz, H. Shapiro, M. Siaut, M. Stanley, M. R. Sussman, A. R. Taylor, A. Vardi, P. von Dassow, W. Vyverman, A. Willis, L. S. Wyrwicz, D. S. Rokhsar, J. Weissenbach, E. V. Armbrust, B. R. Green, Y. Van De Peer and I. V. Grigoriev, Nature, 2008, 456, 239-244.

75 Keywords used for literature search were as follows: 1. biosilica; 2. biosilicification; 3. biogenic silica; $\mathbf{4}$. bioinspired silica; $\mathbf{5}$. bioinspired silicification; 6. biomimetic silica; 7. biomimetic silicification. The keywords $\mathbf{1}$ to $\mathbf{3}$ were collectively termed as biological silica and the remaining as bioinspired silica for data obtained from SciFinder Scholar in February 2011 as shown in Fig. 3b. For Fig. 3c, 1472, items were obtained by summing the data collected by using each of the keywords individually from Web of Knowledge in November 2010.

76 N. Kröger, R. Deutzmann and M. Sumper, Science, 1999, 286, $1129-1132$.

77 N. Kröger, R. Deutzmann and M. Sumper, J. Biol. Chem., 2001, 276, 26066-26070.

78 N. Poulsen and N. Kröger, J. Biol. Chem., 2004, 279, 42993-42999.

79 N. Poulsen, M. Sumper and N. Kröger, Proc. Natl. Acad. Sci. U. S. A., 2003, 100, 12075-12080.

80 A. Scheffel, N. Poulsen, S. Shian and N. Kröger, Proc. Natl. Acad. Sci. U. S. A., 2011, 108, 3175-3180.

81 J. N. Cha, K. Shimizu, Y. Zhou, S. C. Christiansen, B. F. Chmelka, G. D. Stucky and D. E. Morse, Proc. Natl. Acad. Sci. U. S. A., 1999, 96, 361-365.

82 Y. Zhou, K. Shimizu, J. N. Cha, G. D. Stucky and D. E. Morse, Angew. Chem., Int. Ed., 1999, 38, 780-782.

83 C. C. Perry and T. Keeling-Tucker, Chem. Commun., 1998, $2587-2588$.

84 H. A. Currie and C. C. Perry, Ann. Bot., 2007, 100, 1383-1389.

85 H. A. Currie and C. C. Perry, Phytochemistry, 2009, 70, 2089-2095.

86 N. Gong, M. Wiens, H. C. Schroder, E. Mugnaioli, U. Kolb and W. E. G. Muller, J. Exp. Biol., 2010, 213, 3575-3585.

87 M. M. Murr and D. E. Morse, Proc. Natl. Acad. Sci. U. S. A., 2005, 102, 11657-11662.

88 E. Brunner, K. Lutz and M. Sumper, Phys. Chem. Chem. Phys., 2004, 6, 854-857.

89 M. Sumper, Science, 2002, 295, 2430-2433.

90 S. V. Patwardhan, S. A. Holt, S. M. Kelly, M. Kreiner, C. C. Perry and C. F. v. d. Walle, Biomacromolecules, 2010, 11, 3126-3135.

91 T. Mizutani, H. Nagase, N. Fujiwara and H. Ogoshi, Bull. Chem. Soc. Jpn., 1998, 71, 2017-2022.

92 J. N. Cha, G. D. Stucky, D. E. Morse and T. J. Deming, Nature, 2000, 403, 289-292.

93 L. L. Brott, R. R. Naik, D. J. Pikas, S. M. Kirkpatrick, D. W. Tomlin, P. W. Whitlock, S. J. Clarson and M. O. Stone, Nature, 2001, 413, 291-293.

94 S. V. Patwardhan, N. Mukherjee and S. J. Clarson, J. Inorg. Organomet. Polym., 2001, 11, 193-198. 
95 L. Sudheendra and A. R. Raju, Mater. Res. Bull., 2002, 37, 151. 96 S. V. Patwardhan and S. J. Clarson, J. Inorg. Organomet. Polym., $2003,13,49-53$.

97 S. V. Patwardhan and S. J. Clarson, J. Inorg. Organomet. Polym., 2003, 13, 193-203.

98 M. R. Knecht and D. W. Wright, Chem. Commun., 2003, 3038-3039.

99 S. V. Patwardhan, N. Mukherjee, M. Steinitz-Kannan and S. J. Clarson, Chem. Commun., 2003, 1122-1123.

100 S. V. Patwardhan, R. Maheshwari, N. Mukherjee, K. L. Kiick and S. J. Clarson, Biomacromolecules, 2006, 7, 491-497.

101 H. Cui, V. Krikorian, J. Thompson, A. P. Nowak, T. J. Deming and D. J. Pochan, Macromolecules, 2005, 38, 7371.

102 M. M. Tomczak, D. D. Glawe, L. F. Drummy, C. G. Lawrence, M. O. Stone, C. C. Perry, D. J. Pochan, T. J. Deming and R. R. Naik, J. Am. Chem. Soc., 2005, 127, 12577-12582.

103 E. G. Bellomo and T. J. Deming, J. Am. Chem. Soc., 2006, 128, 2276-2279.

104 L. Xia, Y. Liu and Z. B. Li, Macromol. Biosci., 2010, 10, 1566-1575.

105 S. V. Patwardhan, N. Mukherjee and S. J. Clarson, J. Inorg. Organomet. Polym., 2001, 11, 117-121.

106 S. V. Patwardhan and S. J. Clarson, Silicon Chem., 2002, 1, 207-214.

107 S. V. Patwardhan and S. J. Clarson, J. Inorg. Organomet. Polym., 2002, 12, 109.

108 T. Coradin, C. Roux and J. Livage, J. Mater. Chem., 2002, 12, $1242-1244$.

109 S. V. Patwardhan and S. J. Clarson, Polym. Bull., 2002, 48, 367.

110 S. V. Patwardhan, N. Mukherjee and S. J. Clarson, Silicon Chem., $2002,1,47$.

111 A. R. Bassindale, F. K. Brandstadt, T. H. Lane and P. G. Taylor, J. Inorg. Biochem., 2003, 96, 401-406.

112 S. V. Patwardhan, C. Raab, N. Husing and S. J. Clarson, Silicon Chem., 2003, 2, 279.

113 M. R. Knecht and D. W. Wright, Langmuir, 2004, 20, 4728-4732.

114 M. R. Knecht and D. W. Wright, Chem. Mater., 2004, 16, 4890-4895.

115 Y. A. Shchipunov and T. Y. Karpenko, Langmuir, 2004, 20, 3882-3887.

116 D. J. Kim, K. B. Lee, Y. S. Chi, W. J. Kim, H. J. Paik and I. S. Choi, Langmuir, 2004, 20, 7904-7906.

117 S. V. Patwardhan, K. Shiba, C. Raab, N. Huesing and S. J. Clarson, ACS Symp. Ser., 2005, 900, 150-163.

118 M. R. Knecht, S. L. Sewell and D. W. Wright, Langmuir, 2005, 21, 2058-2061

119 R. H. Jin and J. J. Yuan, Macromol. Chem. Phys., 2005, 206, 2160-2170.

120 R. H. Jin and J. J. Yuan, Chem. Commun., 2005, 1399-1401.

121 R.-H. Jin and J.-J. Yuan, Adv. Mater., 2005, 17, 885.

122 D. J. Kim, K. B. Lee, T. G. Lee, H. K. Shon, W. J. Kim, H. J. Paik and I. S. Choi, Small, 2005, 1, 992-996.

123 S. V. Patwardhan, V. P. Taori, M. Hassan, N. R. Agashe, J. E. Franklin, G. Beaucage, J. E. Mark and S. J. Clarson, Eur. Polym. J., 2006, 42, 167-178.

124 J. J. Yuan, P. X. Zhu, N. Fukazawa and R. H. Jin, Adv. Funct. Mater., 2006, 16, 2205-2212.

125 R. H. Jin and J. J. Yuan, Chem. Mater., 2006, 18, 3390-3396.

126 V. V. Annenkov, E. N. Danilovtseva, E. A. Filina and Y. V. Likhoshway, J. Polym. Sci., Part A: Polym. Chem., 2006, 44, 820-827.

127 R. H. Jin and J. J. Yuan, Polym. J., 2007, 39, 822-827.

128 R. H. Jin and J. J. Yuan, Polym. J., 2007, 39, 464-470.

129 J. J. Yuan, O. O. Mykhaylyk, A. J. Ryan and S. P. Armes, J. Am. Chem. Soc., 2007, 129, 1717-1723.

130 P. W. Whitlock, S. V. Patwardhan, M. O. Stone and S. J. Clarson, in Polymer Biocatalysis and Biomaterials Ii, ed. H. N. Cheng and R. A. Gross, 2008, vol. 999, pp. 412.

131 W. D. Marner, A. S. Shaikh, S. J. Muller and J. D. Keasling, Biomacromolecules, 2008, 9, 1-5.

132 V. V. Annenkov, E. N. Danilovtseva, Y. V. Likhoshway, S. V. Patwardhan and C. C. Perry, J. Mater. Chem., 2008, 18, 553-559.

133 S. Masse, G. Laurent, F. Chuburu, C. Cadiou, I. Dechamps and T. Coradin, Langmuir, 2008, 24, 4026-4031.
134 Y. Shchipunov and I. Postnova, Colloids Surf., B, 2009, 74, $172-177$.

135 A. R. Bassindale, P. G. Taylor, V. Abbate and K. F. Brandstadt, J. Mater. Chem., 2009, 19, 7606-7609.

136 S. Masse, G. Laurent and T. Coradin, Phys. Chem. Chem. Phys., 2009, 11, 10204-10210.

137 R. H. Jin and J. J. Yuan, Adv. Mater., 2009, 21, 3750-3753.

138 M. K. Liang, S. V. Patwardhan, E. N. Danilovtseva, V. V. Annenkov and C. C. Perry, J. Mater. Res., 2009, 24, 1700-1708.

139 V. V. Annenkov, S. V. Patwardhan, D. Belton, E. N. Danilovtseva and C. C. Perry, Chem. Commun., 2006, 1521-1523.

140 R. McCann and S. V. Patwardhan, Synthesis of Nano-silica and their Comparison with Industrial Samples, University of Strathclyde, Glasgow, 2010.

141 F. Noll, M. Sumper and N. Hampp, Nano Lett., 2002, 2, 91-95.

142 K. D. Demadis, A. Ketsetzi, K. Pachis and V. M. Ramos, Biomacromolecules, 2008, 9, 3288-3293.

143 K. D. Demadis and E. Neofotistou, Chem. Mater., 2007, 19, 581-587.

144 Z. Amjad, Mineral Scale Formation and Inhibition, Plenum Press, New York, 1995.

145 J. C. Cowan and D. J. Weintritt, Water-formed Scale Deposits, Gulf Publishing, Houston, 1976.

146 K. D. Demadis, E. Mavredaki, A. Stathoulopoulou, E. Neofotistou and C. Mantzaridis, Desalination, 2007, 213, $38-46$.

147 E. Mavredaki, A. Stathoulopoulou, E. Neofotistou and K. D. Demadis, Desalination, 2007, 210, 257-265.

148 A. Stathoulopoulou and K. D. Demadis, Desalination, 2008, 224, 223-230.

149 A. Ketsetzi, A. Stathoulopoulou and K. D. Demadis, Desalination, 2008, 223, 487-493.

150 G. E. Tilburey, PhD Thesis, Understanding molecular interactions in the precipitation and dissolution of silica and silicates under ambient conditions, Nottingham Trent University, 2008.

151 E. A. Coffman, A. V. Melechko, D. P. Allison, M. L. Simpson and M. J. Doktycz, Langmuir, 2004, 20, 8431-8436.

152 M. N. Tahir, P. Theato, W. E. G. Muller, H. C. Schroder, A. Janshoff, J. Zhang, J. Huth and W. Tremel, Chem. Commun., 2004, 2848-2849.

153 S. D. Pogula, S. V. Patwardhan, C. C. Perry, J. W. Gillespie, S. Yarlagadda and K. L. Kiick, Langmuir, 2007, 23, 6677-6683.

154 A. Rai and C. C. Perry, Silicon, 2009, 1, 91-101.

155 A. Rai and C. C. Perry, Langmuir, 2010, 26, 4152-4159.

156 M. C. Gutierrez, M. Jobbagy, N. Rapun, M. L. Ferrer and F. del Monte, Adv. Mater., 2006, 18, 1137.

157 Z. F. Li, X. L. Wei, T. A. Ming, J. F. Wang and T. Ngai, Chem. Commun., 2010, 46, 8767-8769.

158 K. Valle, P. Belleville, F. Pereira and C. Sanchez, Nat. Mater., 2006, 5, 107-111.

159 S. R. Mukai, H. Nishihara and H. Tamon, Chem. Commun., 2004, 874-875.

160 C. J. Brinker, A. J. Hurd, P. R. Schunk, G. C. Frye and C. S. Ashley, J. Non-Cryst. Solids, 1992, 147, 424-436.

161 C. Sanchez, G. Soler-Illia, F. Ribot, T. Lalot, C. R. Mayer and V. Cabuil, Chem. Mater., 2001, 13, 3061-3083.

162 G. J. D. Soler-illia, C. Sanchez, B. Lebeau and J. Patarin, Chem. Rev., 2002, 102, 4093-4138.

163 G. Soler-Illia, E. L. Crepaldi, D. Grosso and C. Sanchez, Curr. Opin. Colloid Interface Sci., 2003, 8, 109-126.

164 C. Sanchez, L. Rozes, F. Ribot, C. Laberty-Robert, D. Grosso, C. Sassoye, C. Boissiere and L. Nicole, C. R. Chim., 2010, 13, 3-39.

165 J. S. Beck, J. C. Vartuli, W. J. Roth, M. E. Leonowicz, C. T. Kresge, K. D. Schmitt, C. T. W. Chu, D. H. Olson, E. W. Sheppard, S. B. McCullen, J. B. Higgins and J. L. Schlenker, J. Am. Chem. Soc., 1992, 114, 10834-10843.

166 X. S. Zhao, G. Q. M. Lu and G. J. Millar, Ind. Eng. Chem. Res., 1996, 35, 2075-2090.

167 B. Boury and R. J. P. Corriu, Chem. Commun., 2002, 795-802.

168 Q. Y. Sun, T. P. M. Beelen, R. A. van Santen, S. Hazelaar, E. G. Vrieling and W. W. C. Gieskes, J. Phys. Chem. B, 2002, 106, $11539-11548$.

169 T. Coradin and J. Livage, J. Sol-Gel Sci. Technol., 2003, 26, $1165-1168$. 
170 Q. Y. Sun, E. G. Vrieling, R. A. van Santen and N. Sommerdijk, Curr. Opin. Solid State Mater. Sci., 2004, 8, 111-120.

171 Chem. Soc. Rev., Hybrid materials themed issue, ed. C. Sanchez, K. J. Shea and S. Kitagawa, 2011, vol. 40, issue 2, pp. 453-1152.

172 D. Avnir, S. Braun, O. Lev and M. Ottolenghi, Chem. Mater., 1994, 6, 1605-1614.

173 A. Coiffier, T. Coradin, C. Roux, O. M. M. Bouvet and J. Livage, J. Mater. Chem., 2001, 11, 2039-2044.

174 J. Livage, T. Coradin and C. Roux, J. Phys.: Condens. Matter, 2001, 13, R673-R691.

175 N. Nassif, O. Bouvet, M. N. Rager, C. Roux, T. Coradin and J. Livage, Nat. Mater., 2002, 1, 42-44.

176 N. Nassif, C. Roux, T. Coradin, M. N. Rager, O. M. M. Bouvet and J. Livage, J. Mater. Chem., 2003, 13, 203-208.

177 J. Livage and T. Coradin, Rev. Mineral. Geochem., 2006, 64, $315-332$.

178 N. Nassif and J. Livage, Chem. Soc. Rev., 2011, 40, 849-859.

179 S. Shtelzer, S. Rappoport, D. Avnir, M. Ottolenghi and S. Braun, Biotechnol. Appl. Biochem., 1992, 15, 227-235.

180 L. M. Ellerby, C. R. Nishida, F. Nishida, S. A. Yamanaka, B. Dunn, J. S. Valentine and J. I. Zink, Science, 1992, 255, 1113-1115.

181 I. Gill and A. Ballesteros, J. Am. Chem. Soc., 1998, 120, 8587.

182 R. B. Bhatia, C. J. Brinker, A. K. Gupta and A. K. Singh, Chem. Mater., 2000, 12, 2434-2441.

183 I. Gill and A. Ballesteros, Trends Biotechnol., 2000, 18, 282-296.

184 M. L. Ferrer, F. del Monte and D. Levy, Chem. Mater., 2002, 14, 3619.

185 J. D. Brennan, D. Benjamin, E. DiBattista and M. D. Gulcev, Chem. Mater., 2003, 15, 737-745.

186 J. A. Cruz-Aguado, Y. Chen, Z. Zhang, N. H. Elowe, M. A. Brook and J. D. Brennan, J. Am. Chem. Soc., 2004, 126, 6878-6879.

187 H. R. Luckarift, J. C. Spain, R. R. Naik and M. O. Stone, Nat. Biotechnol., 2004, 22, 211-213.

188 R. R. Naik, M. M. Tomczak, H. R. Luckarift, J. C. Spain and M. O. Stone, Chem. Commun., 2004, 1684-1685.

189 H. R. Luckarift, G. R. Johnson and J. C. Spain, J. Chromatogr., B: Anal. Technol. Biomed. Life Sci., 2006, 843, 310-316.

190 S. A. Miller, E. D. Hong and D. Wright, Macromol. Biosci., 2006, 6, 839-845.

191 Q. Y. Sun, Y. J. Jiang, Z. Y. Jiang, L. Zhang, X. H. Sun and J. Li, Ind. Eng. Chem. Res., 2009, 48, 4210-4215.

192 S. V. Patwardhan and C. C. Perry, Silicon, 2010, 2, 33-39.

193 K. I. Sano, T. Minamisawa and K. Shiba, Langmuir, 2010, 26, 2231-2234.

194 S. Sjöberg, J. Non-Cryst. Solids, 1996, 196, 51-57.

195 R. Gordon, D. Losic, M. A. Tiffany, S. S. Nagy and F. A. S. Sterrenburg, Trends Biotechnol., 2009, 27, 116-127.

196 N. Poulsen, C. Berne, J. Spain and N. Kroger, Angew. Chem., Int. Ed., 2007, 46, 1843-1846.

197 S. J. Clarson, M. Steinitz-Kannan, S. V. Patwardhan, R. Kannan, R. Hartig, L. Schloesser, D. W. Hamilton, J. K. A. Fusaro and R. Beltz, Silicon, 2009, 1, 79-90.

198 R. Gordon, F. Sterrenburg and K. Sandhage, J. Nanosci. Nanotech., 2005, 5, A special issue on Diatom Nanotechnology.

199 C. Berne, L. Betancor, H. R. Luckarift and J. C. Spain, Biomacromolecules, 2006, 7, 2631-2636.

200 T. Coradin, J. Allouche, M. Boissiere and J. Livage, Curr. Nanosci., 2006, 2, 219-230.

201 F. Neville, M. Broderick, T. Gibson and P. Millner, J. Biotechnol., 2007, 131, S100-S101.

202 L. Betancor and H. R. Luckarift, Trends Biotechnol., 2008, 26, 566-572.

203 M. Ramanathan, H. R. Luckarift, A. Sarsenova, J. R. Wild, E. K. Ramanculov, E. V. Olsen and A. L. Simonian, Colloids Surf., $B, 2009$, 73, 58-64.

204 M. B. Cardoso, H. R. Luckarift, V. S. Urban, H. O'Neill and G. R. Johnson, Adv. Funct. Mater., 2010, 20, 3031-3038.

205 J. B. Kristensen, R. L. Meyer, C. H. Poulsen, K. M. Kragh, F. Besenbacher and B. S. Laursen, Green Chem., 2010, 12, 387-394.

206 H. R. Luckarift, M. B. Dickerson, K. H. Sandhage and J. C. Spain, Small, 2006, 2, 640-643.

207 T. Coradin and J. Livage, Mater. Sci. Eng., C, 2005, 25, 201-205.

208 D. Ivnitski, K. Artyushkova, R. A. Rincon, P. Atanassov, H. R. Luckarift and G. R. Johnson, Small, 2008, 4, 357-364.
209 N. A. Pchelintsev, F. Neville and P. A. Millner, Sens. Actuators, B, 2008, 135, 21-26.

210 V. Vamvakaki, M. Hatzimarinaki and N. Chaniotakis, Anal. Chem., 2008, 80, 5970-5975.

211 M. Hatzimarinaki, V. Vamvakaki and N. Chaniotakis, J. Mater. Chem., 2009, 19, 428-433.

212 F. Neville, N. A. Pchelintsev, M. J. F. Broderick, T. Gibson and P. A. Millner, Nanotechnology, 2009, 20.

213 R. Buiculescu, M. Hatzimarinaki and N. A. Chaniotakis, Anal. Bioanal. Chem., 2010, 398, 3015-3021.

214 P. O'Leary, C. A. van Walree, N. C. Mehendale, J. Sumerel, D. E. Morse, W. C. Kaska, G. van Koten and R. Gebbink, Dalton Trans., 2009, 4289-4291.

215 S. V. Patwardhan and S. J. Clarson, Polymer, 2005, 46, 4474-4479.

216 M. B. Dickerson, R. R. Naik, M. O. Stone, Y. Cai and K. H. Sandhage, Chem. Commun., 2004, 1776-1777.

217 I. A. Banerjee and M. R. Regan, Mater. Lett., 2006, 60, 915-918.

218 S. L. Sewell, R. D. Rutledge and D. W. Wright, Dalton Trans., 2008, 3857-3865.

219 J. L. Sumerel, W. J. Yang, D. Kisailus, J. C. Weaver, J. H. Choi and D. E. Morse, Chem. Mater., 2003, 15, 4804-4809.

220 M. N. Tahir, P. Theato, W. E. G. Muller, H. C. Schroder, A. Borejko, S. Faiss, A. Janshoff, J. Huth and W. Tremel, Chem. Commun., 2005, 5533-5535.

221 P. Curnow, P. H. Bessette, D. Kisailus, M. M. Murr, P. S. Daugherty and D. E. Morse, J. Am. Chem. Soc., 2005, 127, 15749-15755.

222 M. N. Tahir, M. Eberhardt, H. A. Therese, U. Kolb, P. Theato, W. E. G. Muller, H. C. Schroder and W. Tremel, Angew. Chem., Int. Ed., 2006, 45, 4803-4809.

223 N. Kröger, M. B. Dickerson, G. Ahmad, Y. Cai, M. S. Haluska, K. H. Sandhage, N. Poulsen and V. C. Sheppard, Angew. Chem., Int. Ed., 2006, 45, 7239-7243.

224 K. E. Cole and A. M. Valentine, Biomacromolecules, 2007, 8 , 1641-1647.

225 Y. J. Jiang, D. Yang, L. Zhang, L. Li, Q. Y. Sun, Y. F. Zhang, J. Li and Z. Y. Jiang, Dalton Trans., 2008, 4165-4171.

226 Y. J. Jiang, D. Yang, L. Zhang, Q. Y. Sun, X. H. Sun, J. Li and Z. Y. Jiang, Adv. Funct. Mater., 2009, 19, 150-156.

227 D. Kisailus, J. H. Choi, J. C. Weaver, W. J. Yang and D. E. Morse, Adv. Mater., 2005, 17, 314.

228 R. L. Brutchey and D. E. Morse, Angew. Chem., Int. Ed., 2006, 45, 6564-6566.

229 M.-K. Liang, O. Deschaume, S. V. Patwardhan and C. C. Perry, J. Mater. Chem., 2011, 21, 80-89.

230 J. M. Slocik and D. W. Wright, Biomacromolecules, 2003, 4, 1135.

231 Y. Jiang, D. Yang, L. Zhang, Y. Jiang, Y. Zhang, J. Li and Z. Jiang, Ind. Eng. Chem. Res., 2008, 47, 1876-1882.

232 M. B. Dickerson, K. H. Sandhage and R. R. Naik, Chem. Rev., 2008, 108, 4935-4978.

233 S. V. Patwardhan, K. Shiba and S. J. Clarson, Polymer Chemistry, 2004, 45, 612.

234 K. Shiba, T. Honma, T. Minamisawa, K. Nishiguchi and T. Noda, EMBO Rep., 2003, 4, 148-153.

235 T. Van Gerven and A. Stankiewicz, Ind. Eng. Chem. Res., 2009, 48, 2465-2474.

236 P. J. Lopez, C. Gautier, J. Livage and T. Coradin, Curr. Nanosci., 2005, 1, 73-83.

237 J. A. Yates, in Pilot Plants and Scale-up of Chemical Processes, ed. W. Hoyle, The Royal Society of Chemistry, Cambridge, 1997, vol. 1, pp. 3-12.

238 P. N. Sharratt, in Pilot Plants and Scale-up of Chemical Processes, ed. W. Hoyle, The Royal Society of Chemistry, Cambridge, 1997, vol. 1, pp. 13-21.

239 M. Zlokarnik, Scale-up in Chemical Engineering, Wiley-VCH, Weinheim, 2002

240 J. H. Atherton, in Pilot Plants and Scale-up of Chemical Processes, ed. W. Hoyle, The Royal Society of Chemistry, Cambridge, 1999, vol. 2, pp. 19-29.

241 J. C. McAuliffe, W. C. Smith, R. Bond, J. Zimmerman, D. Ward, K. Sanford and T. H. Lane, Polym. Mater: Sci. Eng., 2005, 92, 641.

242 T. Ould-Ely, M. Luger, L. Kaplan-Reinig, K. Niesz, M. Doherty and D. E. Morse, Nat. Protoc., 2011, 6, 97-104. 
243 H. B. Yin, B. Z. Ji, P. S. Dobson, K. Mosbahi, A. Glidle, N. Gadegaard, A. Freer, J. M. Cooper and M. Cusack, Anal. Chem., 2009, 81, 473-478.

244 M. J. Leng, G. E. A. Swann, M. J. Hodson, J. J. Tyler, S. V. Patwardhan and H. J. Sloane, Silicon, 2009, 1, 65-77.

245 C. W. P. Foo, S. V. Patwardhan, D. J. Belton, B. Kitchel, D. Anastasiades, J. Huang, R. R. Naik, C. C. Perry and
D. L. Kaplan, Proc. Natl. Acad. Sci. U. S. A., 2006, 103, 9428-9433.

246 C. Gautier, P. J. Lopez, J. Livage and T. Coradin, J. Colloid Interface Sci., 2007, 309, 44- 48.

247 S. Heinemann, H. Ehrlich, C. Knieb and T. Hanke, Int. J. Mater. Res., 2007, 98, 603-608.

248 S. M. Kang, K. B. Lee, D. J. Kim and I. S. Choi, Nanotechnology, 2006, 17, 4719-4725. 